\title{
MERITOCRACIA ESCOLAR E SUAS INFLUÊNCIAS NA CONDIÇÃO DE JOVEM DOS ALUNOS DA ESCOLA PÚBLICA PORTUGUESA \\ Uma análise sociológica às narrativas oficiais
}

\section{SCHOOL MERITOCRACY AND ITS INFLUENCES ON THE YOUTH CONDITION OF STUDENTS OF THE PORTUGUESE PUBLIC SCHOOL} A sociological analysis of official narratives

\author{
Henrique Ramalho \\ Instituto Politécnico de Viseu, Escola Superior de Educação, Departamento de Psicologia e Ciências da Educação, \\ Centro de Estudos em Educação, Tecnologia e Saúde (CI\&DETS). Rua Maximiano Aragão, 3504-501 Viseu, \\ Portugal. Email: hpramalho@esev.ipv.pt
}

\begin{abstract}
Resumo: Neste estudo, analisam-se os rumos formalmente instituídos da agenda meritocrática do sistema escolar, tendo como referência específica a ocupação de aluno. Tem como principal objetivo compreender o modo como a estrutura legal e normativa do sistema arrola as asserções suscitadas pelos domínios da prestação do serviço educativo, da organização e gestão escolar e da estrutura curricular, culminando na afirmação abundantemente focalizada nos resultados escolares dos alunos. Volvidas cerca de três décadas sobre a publicação da Lei de Bases do Sistema Educativo (LBSE), importa-nos atender à evolução do interesse do legislador em prescrever a educação da juventude, com o encargo de ser aluno, em linha com o argumento da meritocratização. Procedemos a uma análise de conteúdo sistemática da legislação de referência. As nossas conclusões são induzidas na base da hipótese da consolidação de um sistema educativo que se apresenta com uma forte tendência de meritocratização das juventudes que o frequentam.
\end{abstract}

Palavras-chave: meritocracia escolar, condição de jovem, meritocratização do sistema, meritocracia normalizada.

\begin{abstract}
This study analyzes the formally instituted directions of the meritocratic agenda of the school system, having as a specific reference the occupation of a student. Its main goal is to understand how the legal and normative structure of the system lists the assertions raised by the domains of educational service provision, school organization and management, and the curriculum structure, culminating on its main focus on students' school results. Three decades after the publication of the Basic Law of the Educational System (LBES), we analyze the evolution of legislator's interest on prescribing youth's education and, specifically, the occupation of being a student, according to the argument of meritocratization. We proceed with a systematic content analysis of the reference legislation. Our conclusions are based on the hypothesis of the consolidation of the educational system through a strong tendency of meritocratization of the youth.
\end{abstract}

Keywords: school meritocracy, youth condition, meritocratization of the system, normalized meritocracy. 


\section{Introdução}

Com a evolução das políticas educativas, na senda de uma arquitetura do sistema educativo que se tem vindo a (re)instituir com base nos velhos dogmas dos paradigmas socioculturais industrial, racional e, articuladamente, do paradigma tecnológico da educação (Bertrand \& Valois, 1994), confrontamo-nos com uma, de entre outras, possibilidades de análise, compreensão e interpretação do modo como os jovens que frequentam a escola pública portuguesa têm vindo a ser, subtilmente, "institucionalizados" numa arquitetura de escola cada vez mais meritocratizada (Giret, 2006; Tenret, 2011). Tratando-se de um estudo inscrito na sociologia da educação, procura-se analisar os rumos formalmente instituídos da agenda meritocrática do sistema escolar português, privilegiando a intenção de compreender o modo como a estrutura legal e normativa do sistema educativo, tendo em conta a sua orientação para a educação de juventudes, arrola as asserções suscitadas pelos domínios da prestação do serviço educativo, da organização e gestão escolar, da estrutura curricular e consequente oferta educativa/formativa, culminando na afirmação abundantemente focalizada nos resultados escolares dos alunos. Congruentemente, volvidas três décadas sobre a publicação da Lei de Bases do Sistema Educativo (Lei n ${ }^{\circ} 46 / 86$ ), importa-nos atender à evolução do interesse do legislador em prescrever a forma de olhar e conceber a juventude com o encargo de ser aluno, em linha com o argumento da meritocratização do sistema educativo.

Congruentemente, a linha metodológica adotada convoca-nos para um quadro legislativo de referência, estabelecido num horizonte temporal compreendido entre 1999 e 2016, com propósitos de macro análise e consequente interpretação do discurso oficial em torno dos seguintes aspetos: i) quadros de valor e de excelência escolar; ii) metas curriculares e consequente assunção do conjunto de conhecimentos e capacidades essenciais que o aluno tem de adquirir e desenvolver, por ano de escolaridade ou ciclo, nas diferentes disciplinas dos ensinos básico e secundário; iii) organização e a gestão dos currículos dos ensinos básico e secundário, e a avaliação dos conhecimentos a adquirir e das capacidades; iv) estatuto do aluno e ética escolar; v) avaliação das aprendizagens nos ensinos básico e secundário.

Metodologicamente, procedemos a uma análise de conteúdo sistemática da legislação de referência. Desenvolvemos uma sistematização de procedimentos do tipo temático categorial, prosseguindo com a definição das respetivas categorias, atendendo, especialmente, à homogeneidade e pertinência qualitativa dos temas adjacentes (Bardin, 1995), obedecendo a uma metodologia de análise de inferência não frequencial, alinhada com um exercício de agrupamento de significações da mensagem, 
recorrendo a um processo de enumeração de referências específicas empiricamente relevantes (Almeida \& Pinto, 1995).

\section{A condição do jovem que mora no aluno e os processos de institucionalização juvenil na linha da meritocracia normalizada}

A crença, cada vez mais vigorosa, na meritocracia escolar instituída na linha de uma matriz ideológica que, recorrendo à respetiva planificação política do projeto da escolarização contemporânea, procura legitimar e justificar a arquitetura dos atuais sistemas educacionais, reveste-se de um realinhamento da educação, do funcionamento da escola e da ação dos seus atores, com especial destaque para os alunos, pelos paradigmas socioculturais industrial, racional e, articuladamente, do paradigma tecnológico da educação (Bertrand \& Valois, 1994).

Algo a que corresponderá, mais latamente, à produção de conceções políticas instrumentais e utilitárias suscitadas pelas fronteiras filosófico-políticas e ideológicas da contextualização social (e, necessariamente, sociológica) dos papéis, dos saberes, dos processos de legitimação e institucionalização da condição de jovem, de que decorre, também, o estatuto sociocultural dos alunos de uma dada época.

Dizer, também, que aquelas fronteiras filosófico-políticas e ideológicas enunciam-se com recurso a paradigmas centrados na procura e produção de resultados através de testes padronizados, avaliação da performance dos alunos (e professores), responsabilização individual dos atores que são submetidos a esses testes, valorização do desempenho individual proeminente, gestão e realização de resultados educacionais em linha com os moldes empresariais (Ravitch, 2011; Goldthorpe \& Jackson, 2008).

Perante essas considerações, a naturalização da meritocracia na escola pública tem vindo a ser submetida a um fluxo ideológico progressivamente crescente, simetrizado por uma "nova cultura de performatividade competitiva" (Ball, 2002, p. 8) que se tem vindo a instalar na sociedade neoliberal.

A propósito, a própria noção de mérito/meritocracia surge pouco clarificada nos discursos oficiais, limitando-se a surgir semanticamente

(...) diluída nas discussões sobre desempenho e sua avaliação, justiça social, reforma administrativa e do Estado, neoliberalismo, competência, produtividade, etc., e nunca de forma clara e explícita. E para culminar, não há, do ponto de vista histórico, quase nenhuma preocupação da sociedade civil com essa questão, tampouco trabalhos e pesquisa sobre o tema (Barbosa, 2003, p. 21). 
Nesta linha de análise, este trabalho dá especial destaque à noção de meritocracia normalizada, que corresponde ao modo como se formaliza o efeito da escolarização (meritocrática) na formação das juventudes.

Cremos, portanto, que os jovens que frequentam a escola pública têm vindo a ser, subtilmente, institucionalizados numa arquitetura de escola cada vez mais meritocratizada com base na crença do esforço individual enquanto critério mais privilegiado para inscrever a condição de jovem num sistema social e escolar justo para todos, ainda que, paradoxalmente, se afirme, também, como mecanismo de legitimação antecipada das desigualdades sociais em que os jovens são circunstanciados. A isto parece, também, corresponder uma interpretação da planificação social contemporânea assente na definição de desigualdades justas e naturais, dado que resultam do achievment, do acesso a funções e da aquisição de estatutos sociais e culturais, pela via da maior ou menor escolarização e dos seus efeitos em cada um.

Neste caso, a meritocracia normalizada desenvolve uma retórica apologética da igualdade de acesso às oportunidades, aceitando, contudo, as desigualdades multiplicadas por processos normativizados, para muitos, originadas pelo estigma do selfmade man (Dubet, 2001; Contardo, 2008). A propósito, a escola e o consequente efeito planificado de escolarização veiculam, eficazmente, essa retórica normalizada:

Ao atribuir aos indivíduos esperanças de vida escolar estritamente dimensionadas pela sua posição na hierarquia social, e operando uma seleção que - sob as aparências da equidade formal - sanciona e consagra as desigualdades reais, a escola contribui para perpetuar as desigualdades, ao mesmo tempo em que as legitima. Conferindo uma sanção que se pretende neutra, e que é altamente reconhecida como tal, as aptidões socialmente condicionadas que trata como desigualdades de 'dons' ou de mérito, ela transforma as desigualdades de fato em desigualdades de direito, as diferenças econômicas e sociais em 'distinção de qualidade', e legitima a transmissão da herança cultural (Bourdieu, 2007, p. 58).

Tal argumento ganha maior relevância quando se percebe que esse processo de institucionalização das juventudes no quadro mais vasto da planificação social, o processo de escolarização parece corresponder a um sistema arquitetado, de forma muito relevante, para a determinação das futuras e desiguais posições sociais, culturais e profissionais dos jovens. Algo que pode ser perspetivado nos seguintes termos:

A diversificação dos setores e a existência de forte seleção de entrada para alguns deles levam a uma recomposição das desigualdades, geralmente, mais qualitativas. O segundo argumento é o declínio do valor de mercado do diploma. A estrutura das qualificações profissionais evolui mais lentamente do que a do fluxo de licenciados: 
os jovens têm automaticamente cada vez mais dificuldade em encontrar um emprego compatível com o seu nível de qualificação. Por fim, o processo de rebaixamento, criado por esse descompasso entre a oferta e a demanda de graduados, afeta os jovens de maneira muito desigual. Em níveis equiparáveis de educação, género, origem social ou origem étnica irão determinar, em grande parte, as chances dos jovens no mercado de trabalho. Assim, em última análise, a manutenção das desigualdades tanto no acesso a um diploma, como no acesso à posição social no mercado de trabalho, decorre das engrenagens do sistema meritocrático (Giret, 2006, p. 2).

Neste caso, a meritocratização da escola obedece a um propósito fundamental: serve a sociedade não apenas uma função de socialização e institucionalização educacional, mas também uma função de seleção e estruturação social.

A propósito, não será despiciendo alinhar, também, a discussão do ofício de aluno e da sua dimensão mais ou menos humanizante com algumas das mais marcantes mutações paradigmáticas do modelo escolar ocidental da atualidade, das quais destacamos, em particular, a aceção da escola a tempo inteiro como novíssimo modelo de escola pública inaugurado em 2006 (Despacho no 9265-B/2013).

No quadro daquela planificação social (Silva, 1976, pp. 160-162), assiste-se à instalação de um discurso retórico, altamente sedutor, assente na ideia de liberdade de escolha, erupção de opções, utilidade dos serviços públicos de educação, mas também, de ameaça de desemprego e precaridade laboral. É, aliás, recorrente o facto de a agenda neoliberal apropriar-se desses conceitos, expressando-os com um poderoso efeito ameaçador e domesticador das vontades e dos projetos de vida, cooptando as famílias, os alunos, os professores e a sociedade em geral a contribuírem com mais tempo de produtividade, gerando um consenso generalizado sobre a utilidade instrumental da escola a tempo inteiro, e assim determinando as relações sociais, laborais e educativas que passam a vigorar na escola, perspetivando-a como "... uma comunidade. Como parte da sociedade, ela está normalmente estruturada de forma a reproduzir a estrutura social." (Gallo, 2001, p. 145).

É a isto que o imaginário popular sucumbe, sob o efeito sedutor de uma escola que passa a responder aos anseios e aspirações laborais das famílias, sendo-lhes difícil discordar da semântica ideológica que resguarda a escola a tempo inteiro. Assim, ainda que de forma subtil, a escola pública passa a ser instrumentalizada como o mais recente fator de produção, ultrapassando, paradoxalmente, os malefícios reificados pela tese da ineficiência e ineficácia da escola pública. Não raras vezes se afiança que, finalmente, essa mesma escola serve para alguma coisa que se mostra muito mais útil do que a simples prerrogativa de ter mais ou menos qualidade. Ao mesmo tempo, a família passa a ser cúmplice da hiperescolarização dos seus filhos, sendo ela própria adepta de uma escola transbordante (Nóvoa, 2009). 
Aí reside o interesse em perpetuar a presença dos alunos na escola, dado que a reorganiza à sua feição ideológica e interesses de classe, com a aparência de uma escola mais aberta e mais disponível para atender aos interesses e necessidades das famílias e dos alunos que, de todo o modo, foram moldados na forja ideológica do neoliberalismo mais radical, com um poderoso efeito de hiperescolarização dos alunos que, de outra forma, seriam um incómodo e entrave à atividade produtiva das famílias.

Uma outra incidência leva-nos a observar a escola a tempo inteiro enquanto novíssimo modelo da escola pública recém instituído, que explicita quatro dimensões (Pires, 2012), que têm servido para a consolidar na base de uma retórica discursiva eufémica: $i$ ) a dimensão educativa, porque retoma e reforça o paradigma da escola tradicional, dando maior ênfase ao efeito de escolarização dos espaços libertos desse mesmo efeito, ainda que articulando momentos de escolarização que se distinguem pela curricularização forte e pela descurricularização débil (no caso das atividades de enriquecimento curricular); ii) a dimensão política, dotando a escola a tempo inteiro de um novo significado político do espaço e tempo da escola pública, incluindo a reafirmação preponderante da velha imagem do Estado educador (ainda que não abdicando da dimensão avaliativa); iii) a dimensão administrativa, reportando-se a uma nova racionalidade da organização do serviço público de educação, com a interferência de outros atores, ditos não tradicionais (como disso são exemplos as parcerias estabelecidas com entidades privadas e com as próprias autarquias locais); iv) a dimensão vocacionalista socioprofissional, que inscreve o ofício de aluno num mecanismo de alunização especialmente orientado para a sua preparação para desempenhar uma função confinada à lógica da divisão técnica do trabalho, no quadro de uma arquitetura social de elevada diferenciação hierárquica.

Em contracorrente com os argumentos críticos que as teorias da reprodução social convocam, diríamos que a escola meritocrática, dado que é fortemente normalizada, tende a ocultar o velho pressuposto de que os sistemas escolares têm um papel central na transformação das desigualdades sociais em desigualdades escolares (e vice-versa), ao mesmo tempo que idolatra o que acontece durante a escola e desvaloriza o que acontece depois da escola, cometendo a cada aluno a responsabilidade pelo seu sucesso ou fracasso escolar, precisamente na base de desigualdades sociais e escolares variáveis amainadas, geridas e, até, dirimidas pelo aparelho normativo.

No que nos interessa, a noção que aqui introduzimos de meritocracia normalizada concretiza-se pela sua própria natureza arqueológica, juridicamente instituída e materializada na forma de regulamentos específicos dos quadros de honra, mérito ou excelência (Despacho Normativo $n^{\circ}$ 102/1990), contribuindo para um sistema 
educativo que transforma o mérito na “(...) cultura legítima, isto é, a cultura dotada da legitimidade dominante, não [sendo] outra coisa que o arbitrário cultural dominante, na medida em que ele é desconhecido em sua verdade objetiva de arbitrário cultural e de arbitrário cultural dominante (Bourdieu \& Passeron, 1982, p. 36).

Acercamo-nos, aqui, perante nova encruzilhada suscitada por Leonor Lima Torres (2013, p. 154): a escola meritocrática, sedeada no rumo da excelência escolar, circunstancia-se em qual dos seguintes polos? i) imposição política; ii) opção organizacional; iii) efeito cultural? Ainda que a autora dê um enfoque mais privilegiado a "ilustração [de uma] visão estratégica e cultural", explicando que

A crescente adesão, por parte das instituições educativas, a práticas de distinção académica, de que são exemplo, os quadros de excelência, os concursos, os prémios de mérito e outras formas de incentivo da competição, poderá traduzir uma reação contextual de algumas escolas à pressão bipolar de são objeto, a difícil conciliação entre mais escola - melhor escola. Perante este cenário, podemos equacionar se o culto do mérito e da excelência académica constitui uma (mera) opção organizacional, resultante de uma escolha política deliberada e intencional, ou antes, se representa uma consequência de um longo processo de institucionalização identitária, configurando deste modo um efeito sociocultural? No caso em estudo, os indícios empíricos que temos vindo a coletar, apontam de forma inequívoca para a segunda hipótese, já que a institucionalização de quadros de excelência associada a outros cerimoniais de distinção inscreve-se no percurso identitário deste liceu, ajudando mesmo a reforçar a imagem socialmente difundida de diferenciação académica e de uma certa elitização do ensino.

Não obstante a centralidade dos fatores simbólico-culturais concedida pelo estudo da autora, cremos que a base ideológica emanada do espectro normativo encontra-se mais a montante daquele argumento, sendo legítimo argumentar que o sedimento cultural associado à perspetivação da excelência escolar, com grande probabilidade, não poderá ser alheado daquela base normativa, por definição, profundamente ideológica.

A propósito, veja-se, por exemplo, o Estatuto do Aluno e Ética Escolar (Lei $\left.n^{\circ} 51 / 2012\right)$, que, ao apelar ao escrutínio dos resultados, subentende, na sua arqueologia jurídica, a materialização da ideologia dos resultados e do sucesso, rapidamente transformada na subsidiária ideologia do mérito e da excelência individuais dos alunos, num claro efeito de emulação coletiva subordinante das juventudes à competição com o outro (Palhares, 2014), intermediada pelos princípios neoliberais da avaliação e da accountability (Afonso, 2012, 2013).

Apelando ao enquadramento propiciado por aquele estatuto e demais legislação conexa, a configuração normativa da meritocracia escolar surge como “(...) a 
única via ao mesmo tempo justa e eficaz de repartir os lugares (desiguais) nas sociedades democráticas" (Giret, 2006, p. 1). É, também, a constatação de que o discurso oficial que prescreve o processo de escolarização dos jovens na base de princípios meritocráticos explícitos, emergindo uma narrativa, privilegiadamente, sedeada em diplomas legais, que exprimem as expectativas produtivistas, ainda que de feição utilitária e instrumental, depositadas na escola e nos seus atores, com destaque para o que exige dos alunos, discursivamente reduzido à sua desejável e (im)provável inserção no mercado de trabalho/vida ativa.

Eis que surge uma encruzilhada em que a condição de jovem pode ser circunstanciada na agenda da meritocracia escolar: uma democracia escolar - escolarização igual para todos, assente na ideologia da igualdade de oportunidades (Quaresma, 2011; Torres \& Quaresma, 2017) ou uma elitização dos méritos (social e culturalmente reproduzidos)? O caráter dilemático dessa encruzilhada tem contribuído para uma ressemantização do significado dado ao mérito escolar, no sentido em que o argumento mais progressista que lhe poderia ser conectado - a democratização dos processos escolares com tradução num pretenso acesso e sucesso para todos - tem sido posto em causa por elevados índices de insucesso escolar em matérias ditas essenciais e por taxas incómodas de abandono precoce do sistema escolar público. Aquele efeito de ressemantização tem conduzido à introdução de novas nomenclaturas nos discursos oficiais, de que se destaca as expressões, já muito recorrentes nas ações de avaliação externa das escolas, da oferta (diferenciada) de escola, do efeito escola ou efeito esperado e da qualidade do sucesso (Lei $\left.n^{\circ} 31 / 2002\right)$, como que se de uma absolvição se tratasse ao culto da meritocracia escolar (Allen, 2011; Duru-Bellat, 2010; McNamee \& Miller, 2004). A questão essencial que se segue a estas ilações será sempre: uma escola meritocrática para quem? (Duru-Bellat \& Tenret, 2012). Certamente, não servirá $a$ e para todos. Isto poderá querer dizer que a ideologia da meritocracia escolar resguarda, sob a capa da sua própria retórica que a todos seduz, outras escolas, para outros alunos não (pré)destinados ao mérito oficialmente normalizado.

Com efeito, a noção de meritocracia normalizada encontra a sua principal base de legitimação na democracia dos méritos, na senda da qual a escola meritocrática proclama e reclama a sua função de instrumento de mobilidade social (Valle, 2013), cujo pendor se afirma mais produtivista, mais performativo e menos cívico e crítico (Palhares, 2014).

$\mathrm{Na}$ "maratona" da meritocracia é mais fácil entrar do que permanecer. Porque corresponde a um modelo de distribuição de recursos ou vantagens, cujo critério base a ser considerado é o desempenho e as aptidões individuais de cada aluno, fundamenta moralmente a agenda ideológica da escola neoliberal, como fase preponderante (e, 
em alguma medida, prévia) da planificação da distribuição de recursos na sociedade. O recurso que mais importa nesta fase será, sem dúvida, o conhecimento escolar e o quadro de competências que cada um conseguir arrecadar, graças ao seu esforço individual, acreditando-se que um acesso mais substancial a esse recurso permitirá, no futuro, um acesso mais privilegiado a outros recursos sociais.

Na senda da ascensão da meritocracia (Young, 1961), o mérito tem vindo a ser prosseguido na linha filosófico-política e funcionando como instrumento de seleção e segregação social dos jovens alunos da nossa escola, promovendo uma inclusão escolar enviesada, sem atender às diferenças socias e culturais de partida (Goldthorpe \& Jackson, 2008). Mostra-se, aliás, adicta à ênfase dada ao projeto da escola meritocrática consolidado por argumentos mais aprofundados no âmbito das teorias do capital humano apologistas do melhor uso possível do material humano nos processos produtivos, em que a seleção de alguns corresponde à rejeição de muitos (Young, 1961; Piza, 1985). Propicia-se aqui a ideia de explorar, ao máximo, as potencialidades da escola e seus atores (alunos e professores) focada nos valores de eficiência, excelência e competência. A noção de meritocracia normalizada propicia, ainda que implicitamente, a ideia de educar/formar (melhor) os mais capazes (Valle \& Ruschel, 2009) sedimentada pelos efeitos da vocacionalização dos alunos.

A propósito, a expressão "a escola faz as juventudes" (Dayrell, 2007, p. 1105) ganha especial destaque nesta análise, dado que convoca a relação formalmente estabelecida entre a escola e as juventudes que acolhe, educa, forma, transforma e sobre as quais cria expectativas:

(...) existe uma dupla dimensão presente quando falamos em condição juvenil. Refere-se ao modo como uma sociedade constitui e atribui significado a esse momento do ciclo da vida, no contexto de uma dimensão histórico-geracional, mas também à sua situação, ou seja, o modo como tal condição é vivida a partir dos diversos recortes referidos às diferenças sociais - classe, gênero, etnia etc. (Dayrell, 2007, p. 1108).

Não podemos reduzir tal análise a uma relação simétrica entre a escola e os alunos, pelo que as tensões e cumplicidades que se vão desenvolvendo entre estas duas categorias sociais não dependem, em exclusivo, das circunstâncias isoladas com que cada uma delas se posiciona em relação à outra. Pelo contrário, outras categorias, como a ideologia, a sociedade, as organizações e a cultura tendem a ocupar um lugar de destaque como intermediárias da relação que se vai estabelecendo e construindo entre os jovens e a escola (Abramo, 2005). No limite, à escola e ao sistema educativo vai sendo acoplada uma determinada expectativa programática sobre como se espera que forme as juventudes. Eis que à escola se associa uma conditio necessária para que se fabrique uma determinada maneira de se ser jovem (Dayrell, 
2007), precisamente na linha em que "A escola, em cada momento histórico, constitui uma expressão e uma resposta à sociedade na qual está inserida. Nesse sentido, ela nunca é neutra, mas sempre ideológica e politicamente comprometida. Por isso cumpre uma função específica" (Gasparin, 2005, p. 2).

De uma forma mais lata, referimo-nos ao modo como a sociedade procede à arquitetura de um sistema escolar no sentido de lhe conectar determinados sentidos e significados do ser jovem. Congruentemente, o ímpeto cultural e ideológico da modernidade, sedeado no ideário iluminista, introduziu sentidos e significados do ato de educar como processo de orientação da educação dos sujeitos, em linha com a prerrogativa do "cuidado do outro" (Bonamigo, 2016. p. 139), pelo que, consequentemente, ser jovem passou a conotar-se com a ideia de ser aluno. Volvidos cerca de dois séculos, o processo de escolarização das camadas mais jovens ampliou-se pela via da normalização, institucionalização e formalização dos sistemas escolares, granjeando o efeito de colonização do espaço e tempo de desenvolvimento do sujeito jovem:

\footnotetext{
Os alunos partilham - com os prisioneiros, os militares, alguns indivíduos internados ou trabalhadores mais desqualificados - a condição daqueles que não têm, para se defenderem contra o poder da instituição e dos seus chefes diretos, mais nenhuns outros meios que não sejam a astúcia, a subserviência, o fingimento. Pensar, antes de mais, em ultrapassar a situação, em adaptar as estratégias que garantam a sobrevivência e uma certa tranquilidade, é humano. Mas o exercício intensivo do ofício de aluno pode também produzir efeitos perversos: trabalhar só por uma nota, construir uma relação também utilitarista com o saber, com o trabalho, com o outro (Perrenoud, 1995, p. 17).
}

Por força dessa mesma conceção da condição de jovem, é notória a preponderância com que o processo de escolarização tem vindo a ser normalizado (ainda que subjetivamente experienciado), quase com sentido único e com caráter obrigatório, com feição instrutiva e disciplinadora, a que corresponde, também, um controlo exercido a partir de uma estrutura escolar de classe, com o objetivo de os jovens praticarem um determinado estilo de vida, na condição irrevogável de sujeitos obedientes e propagadores desse modo de se comportar e de entender a realidade social (Aron, 1991; Durkheim, 2008), que pode ser entendido da seguinte forma:

(...) a manutenção da crença no poder mítico da educação como elemento de ascensão social constitui-se, verdadeiramente, como um importante instrumento de controle social interno ou consensual, ou na formulação gramsciana como uma forma de obter o consentimento ativo dos governados (Miletto, 2009, p. 114).

Diríamos mesmo que, em primeira instância, ser aluno submete o sujeito jovem a um estádio temporário de ignorância e ao ofício instituído de aperfeiçoamento da 
sua cognoscência vocacionalista sobre a realidade social em que se vêinserido, pelo que

(...) a visão economicista constitui o determinante fundamental das propostas formuladas, não porque elas formem quadros qualificados para a inserção social no núcleo orgânico do processo produtivo, mas porque visam criar vias de escape para aqueles que não serão efetivamente incorporados, mas que precisam ser mantidos sob controle e conformados de modo que não venham a se tornar geradores de instabilidade social (Rummert \& Alves, 2010, p. 525).

Eis que se inscreve o sujeito jovem na condição institucional e normativa de ofício de aluno (Perrenoud, 1995), na perspetiva de um ator social inacabado, incompleto e que, por isso, carece de ser iluminado, orientado, alimentado e controlado por um conhecimento de feição, não raras vezes, essencialista e instrumental (Adorno \& Horkheimer, 1995).

\section{Notas metodológicas}

Tomando como referência fundamental os pressupostos e procedimentos da análise sistemática de conteúdo, enquanto técnica de tratamento do material empírico de natureza documental, o campo metodológico de referência é analítico compreensivo, adotando o confronto entre um quadro teórico e concetual de referência e os dados empíricos recolhidos e sistematizados com recurso à técnica temático categorial (Poirier, Valladon \& Raybant, 1983). Ao incorrer numa dimensão analítico compreensiva, o trabalho metodológico adotado priorizou um procedimento interpretativo subordinado às problematizações inicialmente mobilizadas, com recurso a um sistema de conceitos teóricos com a função de corresponderem a um primeiro momento de análise, em relação ao objeto de estudo. Um trabalho que se baseou num processo analítico com recurso à construção de tipologias, categorias (subcategorias) e temas adjacentes simetrizados com os respetivos "recortes de nível semântico" alinhados com o sentido dado à "noção de tema". Configuramos, assim, uma "análise temática" com recurso a "proposições portador[as] de significações isoláveis" ou "palavras plenas" (Bardin, 1995, p. 104-105), pela execução de recortes de nível semântico. Com a pretensão de descrever determinadas racionalidades discursivas, tal procedimento metodológico procurou analisar e interpretar o sentido dessas racionalidades, recorrendo a uma "análise temática" com recurso a "proposições portador[as] de significações isoláveis", "palavras plenas" (Bardin, 1995, p. 104-105), ou a "códigos de definição da situação", que passa por descobrir "núcleos de sentido" (Bogdan \& Biklen, 1994, p. 221-223). Para tal, foram construídas sinopses dos conteúdos documentais (Poirier, Valladon \& Raybant, 1983), submetendo-as a um processo sistemático de análise 
categorial e temática em profundidade (Bardin, 1995), para, a partir daqui, avançar para um domínio interpretativo, mobilizando novos conceitos e (re)construindo asserções teóricas potencialmente compreensivas do objeto em estudo. Congruentemente, não foi objetivo deste procedimento metodológico organizar uma demonstração causal, correspondendo, antes, a uma orientação de inferência não frequencial, suscitando um processo de produção de sentidos e significados de plausibilidade dos dados empíricos mobilizados. Finalmente, dizer que, tratando-se de uma análise indutiva (Demazière \& Dubar, 1997), procedeu-se a um processo de (re)teorização com recurso à interpelação indutiva dos dados empíricos.

\section{Apresentação, Análise e Discussão dos Dados}

\section{Categorização, codificação e sistematização dos dados documentais}

O critério de análise que envolveu as respetivas categorias temáticas (Bardin, 2011, p. 147) baseou-se numa classificação extraída do corpus textual de cada um dos diplomas legais analisados, mediados pelos referenciais teóricos que mobilizamos para o efeito.

No cômputo global, o nosso corpus documental decorreu das atuais prioridades mais explícitas, suscitadas por parte do legislador em torno dos seguintes aspetos: avaliação educacional, valoração do trabalho escolar, currículo, metas e objetivos educacionais, disciplina e comportamento dos alunos, com especial incidência e interferência no ato de ser aluno. Integrou os seguintes documentos:

Tabela 1 Corpus documental

\begin{tabular}{|c|c|}
\hline Documento & Designação \\
\hline D1 & $\begin{array}{l}\text { Despacho Normativo n. }{ }^{\circ} 102 / 1990 \text {, de } 12 \text { de setembro - estabelece os quadros de valor e de } \\
\text { excelência escolar }\end{array}$ \\
\hline $\mathrm{D} 2$ & Lei n. ${ }^{\circ} 49 / 2005$, de 30 de agosto - segunda alteração à Lei de Bases do Sistema Educativo \\
\hline D3 & $\begin{array}{l}\text { Despacho n. }{ }^{\circ} 5306 / 2012 \text {, de } 18 \text { de abril - cria o grupo de trabalho de reformulação das Metas } \\
\text { Curriculares, o qual tem por missão identificar o conjunto de conhecimentos e capacidades } \\
\text { essenciais que o aluno tem de adquirir e desenvolver, por ano de escolaridade ou ciclo, nas } \\
\text { diferentes disciplinas dos ensinos básico e secundário }\end{array}$ \\
\hline D4 & $\begin{array}{l}\text { Decreto-Lei n. }{ }^{\circ} 139 / 2012 \text {, de } 5 \text { de julho - estabelece os princípios orientadores da organização e } \\
\text { da gestão dos currículos dos ensinos básico e secundário, da avaliação dos conhecimentos a } \\
\text { adquirir e das capacidades }\end{array}$ \\
\hline D5 & Lei n. ${ }^{\circ} 51 / 2012$, de 5 de setembro - aprova o Estatuto do Aluno e Ética Escolar \\
\hline D6 & $\begin{array}{l}\text { Decreto-Lei n. }{ }^{\circ} 91 / 2013 \text {, de } 10 \text { de julho - procede à primeira alteração ao Decreto-Lei } \\
\text { n. }{ }^{\circ} 139 / 2012 \text {, de } 5 \text { de julho, que estabelece os princípios orientadores da organização e da gestão } \\
\text { dos currículos dos ensinos básico e secundário, da avaliação dos conhecimentos a adquirir e das } \\
\text { capacidades a desenvolver pelos alunos }\end{array}$ \\
\hline D7 & $\begin{array}{l}\text { Decreto-Lei n. }{ }^{\circ} 17 / 2016 \text {, de } 4 \text { de abril - estabelece os princípios orientadores da avaliação das } \\
\text { aprendizagens nos ensinos básico e secundário }\end{array}$ \\
\hline
\end{tabular}


Em conformidade com a metodologia explanada, operamos com os seguintes elementos de codificação e categorização dos dados documentais, a que corresponde à subsequente "unitarização ou transformação do conteúdo em unidades" (Moraes, 1999, p. 10) e descrição em função das respetivas unidades de contexto:

Tabela 2 Referencial de codificação e categorização dos dados documentais relativo ao documento 1

\begin{tabular}{|c|c|c|}
\hline Categorias temáticas & Unidades de análise & Unidades de contexto \\
\hline \multirow{8}{*}{$\begin{array}{l}\text { CT1 - Disposições gerais } \\
\text { relativas à meritocracia } \\
\text { escolar (alunos) }\end{array}$} & $\begin{array}{l}\text { UA1 - O mérito como } \\
\text { ethos cultural do } \\
\text { sistema educativo }\end{array}$ & $\begin{array}{l}\text { "... prosseguir eficazmente aqueles objectivos, } \\
\text { reconhecendo sistematicamente os alunos que se } \\
\text { distinguem pelo seu valor, demonstrado na superação de } \\
\text { dificuldades ou no serviço aos outros e pela excelência do } \\
\text { seu trabalho." } \\
\text { "Os quadros de valor e de excelência destinam-se a tornar } \\
\text { patente o reconhecimento de aptidões e atitudes dos alunos } \\
\text { ou grupos de alunos do } 2 .^{\circ} \text { e } 3 .^{\circ} \text { ciclos do ensino básico e } \\
\text { do ensino secundário, público, particular ou cooperativo, } \\
\text { que tenham evidenciado valor e excelência nos domínios } \\
\text { cognitivo, cultural, pessoal ou social, bem como a atribuir } \\
\text { prémios, em casos específicos e excepcionais." }\end{array}$ \\
\hline & $\begin{array}{l}\text { UA2 - Alusões do } \\
\text { sistema educativo à } \\
\text { justiça escolar e social }\end{array}$ & \\
\hline & \multirow{5}{*}{$\begin{array}{l}\text { UA3 - Uma arquitetura } \\
\text { burocrática do sistema } \\
\text { educativo baseada em } \\
\text { aprendizagens } \\
\text { diferenciadas e na } \\
\text { distribuição } \\
\text { diferenciada do saber } \\
\text { escolar }\end{array}$} & $\begin{array}{l}\text { "A condição mínima de candidatura ao quadro de } \\
\text { excelência anual é a obtenção de média de } 5 \text { nas } \\
\text { disciplinas ou áreas disciplinares, ponderada pela carga } \\
\text { horária semanal, ou média de } 16, \text { também ponderada." }\end{array}$ \\
\hline & & $\begin{array}{l}\text { "a) Quadro de valor - no fim de cada ciclo do ensino básico } \\
\text { ou no fim do ensino secundário devem ser propostas os } \\
\text { alunos que permaneceram no quadro anual de valor da } \\
\text { escola durante todos os anos desse ciclo do ensino básico } \\
\text { ou em todos os anos do ensino secundário;" }\end{array}$ \\
\hline & & $\begin{array}{l}\text { "b) Quadro de excelência, no fim de cada ciclo do ensino } \\
\text { básico ou no fim do ensino secundário devem ser propostos } \\
\text { todos os alunos que permaneceram no quadro anual de } \\
\text { excelência da escola em todos os anos desse ciclo do } \\
\text { ensino básico ou em todos os anos do ensino secundário." }\end{array}$ \\
\hline & & $\begin{array}{l}\text { "1 - O quadro nacional de valor reconhece os alunos que } \\
\text { permaneceram no quadro regional de valor } \\
\text { cumulativamente no } 3 .^{\circ} \text { ciclo do ensino básico e no ensino } \\
\text { secundário. }\end{array}$ \\
\hline & & $\begin{array}{l}2 \text { - O quadro nacional de excelência reconhece os alunos } \\
\text { que permaneceram no quadro regional de excelência } \\
\text { cumulativamente no } 3 .^{\circ} \text { ciclo do ensino básico e no ensino } \\
\text { secundário." }\end{array}$ \\
\hline & $\begin{array}{l}\text { UA4 - Alusão ao mérito } \\
\text { como mecanismo social } \\
\text { de competição }\end{array}$ & \\
\hline
\end{tabular}




\begin{tabular}{|c|c|c|}
\hline \multirow{6}{*}{$\begin{array}{l}\text { CT2 - Relação da } \\
\text { condição de aluno com a } \\
\text { ideia de mérito }\end{array}$} & \multirow{4}{*}{$\begin{array}{l}\text { UA5 - Definição } \\
\text { meritocrática de aluno }\end{array}$} & $\begin{array}{l}\text { "O quadro de excelência reconhece os alunos que revelam } \\
\text { excelentes resultados escolares e produzem trabalhos } \\
\text { académicos ou realizam actividades de excelente } \\
\text { qualidade, quer no domínio curricular, quer no domínio dos } \\
\text { complementos curriculares." }\end{array}$ \\
\hline & & $\begin{array}{l}\text { "2 - Os prémios para o quadro de excelência podem } \\
\text { consistir em bolsas de estudo para o prosseguimento de } \\
\text { estudos numa instituição de ensino superior." }\end{array}$ \\
\hline & & $\begin{array}{l}\text { "3 - Devido à função educativa descrita no número anterior, } \\
\text { os prémios devem consistir sobretudo em instrumentos, } \\
\text { materiais ou condições com relação intrínseca com a } \\
\text { actividade premiada e que permitam o seu prosseguimento } \\
\text { a um nível de conhecimentos mais avançado ou a sua } \\
\text { continuidade a nível profissional." }\end{array}$ \\
\hline & & $\begin{array}{l}\text { "A condição mínima de candidatura ao quadro de } \\
\text { excelência anual é a obtenção de média de } 5 \text { nas } \\
\text { disciplinas ou áreas disciplinares, ponderada pela carga } \\
\text { horária semanal, ou média de 16, também ponderada." }\end{array}$ \\
\hline & $\begin{array}{l}\text { UA6 - Um sentido de } \\
\text { sucesso escolar } \\
\text { decorrente da } \\
\text { motivação e empenho } \\
\text { individual }\end{array}$ & \\
\hline & $\begin{array}{l}\text { UA7 - A ideia do poder } \\
\text { do mérito atribuído ao } \\
\text { aluno }\end{array}$ & $\begin{array}{l}\text { "...reconhecendo sistematicamente os alunos que se } \\
\text { distinguem pelo seu valor, demonstrado na superação de } \\
\text { dificuldades ou no serviço aos outros e pela excelência do } \\
\text { seu trabalho;" }\end{array}$ \\
\hline \multirow{4}{*}{ CT3 - Avaliação e mérito } & $\begin{array}{l}\text { UA8 - Avaliação } \\
\text { alinhada com a ideia } \\
\text { genérica de "mérito" }\end{array}$ & $\begin{array}{l}\text { "1 - Os quadros de valor e de excelência destinam-se a } \\
\text { tornar patente o reconhecimento de aptidões e atitudes dos } \\
\text { alunos ou grupos de alunos do } 2 .^{\circ} \text { e } 3 .^{\circ} \text { ciclos do ensino } \\
\text { básico e do ensino secundário, público, particular ou } \\
\text { cooperativo, que tenham evidenciado valor e excelência nos } \\
\text { domínios cognitivo, cultural, pessoal ou social, bem como a } \\
\text { atribuir prémios, em casos específicos e excepcionais. }\end{array}$ \\
\hline & & $\begin{array}{l}2 \text { - Os quadros de valor e de excelência assumem } \\
\text { características diversas em função do tipo de aptidões e de } \\
\text { atitudes que são reconhecidas, bem como da respectiva } \\
\text { amplitude valorativa." }\end{array}$ \\
\hline & \multirow{2}{*}{$\begin{array}{l}\text { UA9 - Interseções } \\
\text { estabelecidas entre } \\
\text { avaliação, } \\
\text { objetivos/metas/ } \\
\text { competências e mérito } \\
\text { escolar }\end{array}$} & $\begin{array}{l}\text { "1 - Os quadros de valor e de excelência destinam-se a } \\
\text { tornar patente o reconhecimento de aptidões e atitudes dos } \\
\text { alunos ou grupos de alunos do } 2 .^{\circ} \text { e } 3 .^{\circ} \text { ciclos do ensino } \\
\text { básico e do ensino secundário, público, particular ou } \\
\text { cooperativo, que tenham evidenciado valor e excelência nos } \\
\text { domínios cognitivo, cultural, pessoal ou social, bem como a } \\
\text { atribuir prémios, em casos específicos e excepcionais. }\end{array}$ \\
\hline & & $\begin{array}{l}2 \text { - Os quadros de valor e de excelência assumem } \\
\text { características diversas em função do tipo de aptidões e de } \\
\text { atitudes que são reconhecidas, bem como da respectiva } \\
\text { amplitude valorativa." }\end{array}$ \\
\hline
\end{tabular}




\begin{tabular}{|c|c|c|}
\hline & & $\begin{array}{l}\text { "O quadro de excelência reconhece os alunos que revelam } \\
\text { excelentes resultados escolares e produzem trabalhos } \\
\text { académicos ou realizam actividades de excelente } \\
\text { qualidade, quer no domínio curricular, quer no domínio dos } \\
\text { complementos curriculares." }\end{array}$ \\
\hline & $\begin{array}{l}\text { UA10 - Enfoque nos } \\
\text { resultados individuais e } \\
\text { o direito de ser } \\
\text { reconhecido pelas } \\
\text { competências } \\
\text { adquiridas }\end{array}$ & $\begin{array}{l}\text { "1 - Os quadros de valor e de excelência destinam-se a } \\
\text { tornar patente o reconhecimento de aptidões e atitudes dos } \\
\text { alunos ou grupos de alunos do } 2 .^{\circ} \text { e } 3^{\circ} \text { ciclos do ensino } \\
\text { básico e do ensino secundário, público, particular ou } \\
\text { cooperativo, que tenham evidenciado valor e excelência nos } \\
\text { domínios cognitivo, cultural, pessoal ou social, bem como a } \\
\text { atribuir prémios, em casos específicos e excepcionais. }\end{array}$ \\
\hline & & $\begin{array}{l}2 \text { - Os quadros de valor e de excelência assumem } \\
\text { características diversas em função do tipo de aptidões e de } \\
\text { atitudes que são reconhecidas, bem como da respectiva } \\
\text { amplitude valorativa." }\end{array}$ \\
\hline \multirow{4}{*}{$\begin{array}{l}\text { CT4 - Gestão escolar } \\
\text { e mérito }\end{array}$} & $\begin{array}{l}\text { UA11 - O processo de } \\
\text { certificação como face } \\
\text { oficial de medição } \\
\text { (diferenciada) do mérito }\end{array}$ & \\
\hline & $\begin{array}{l}\text { UA12 - "Terapias" } \\
\text { (pedagógicas) } \\
\text { alternativas para a } \\
\text { universalização } \\
\text { hierarquizada do mérito }\end{array}$ & \\
\hline & \multirow{2}{*}{$\begin{array}{l}\text { UA13 - A normalização } \\
\text { dos prémios de } \\
\text { mérito/excelência e a } \\
\text { ideia de recompensa }\end{array}$} & $\begin{array}{l}\text { "Considerando, ainda, que as actividades do sistema } \\
\text { pedagógico-didáctico muito se enriquecem se for criado e } \\
\text { introduzido um mecanismo adequado de promoção escolar } \\
\text { que não só estimule o aluno para a realização do trabalho } \\
\text { escolar, individual ou colectivo, como também lhe } \\
\text { reconheça, valorize e premeie as aptidões e atitudes } \\
\text { reveladas ao nível cultural, pessoal e social;" }\end{array}$ \\
\hline & & $\begin{array}{l}\text { "1 - São criados os quadros de valor e de excelência a nível } \\
\text { da escola, a nível regional e a nível nacional para os alunos } \\
\text { das escolas do } 2 .^{\circ} \text { e } 3 .^{\circ} \text { ciclos do ensino básico e para os } \\
\text { alunos das escolas do ensino secundário, públicas, } \\
\text { particulares ou cooperativas." }\end{array}$ \\
\hline
\end{tabular}


Tabela 3 Referencial de codificação e categorização dos dados documentais relativo ao documento 2

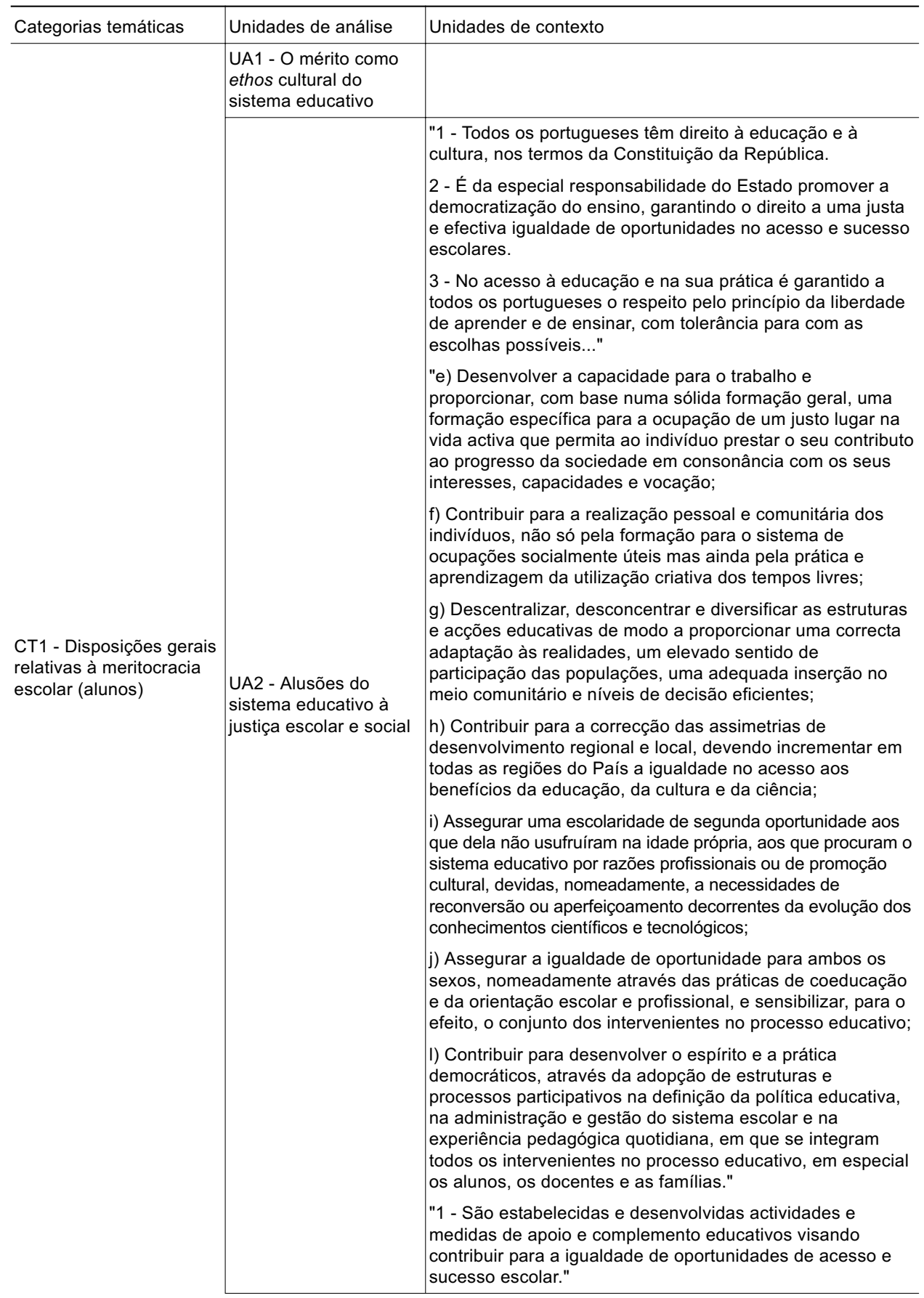


CT2 - Relação da condição de aluno com a ideia de mérito

CT4 - Gestão escolar e mérito

CT3 - Avaliação e mérito

\begin{tabular}{l}
\hline \\
CT4 - Gestão escolar e \\
mérito
\end{tabular}

\begin{tabular}{|c|c|}
\hline $\begin{array}{l}\text { UA3 - Uma arquitetura } \\
\text { burocrática do sistema } \\
\text { educativo baseada em } \\
\text { aprendizagens } \\
\text { diferenciadas e na } \\
\text { distribuição } \\
\text { diferenciada do saber } \\
\text { escolar }\end{array}$ & \\
\hline $\begin{array}{l}\text { UA4 - Alusão ao mérito } \\
\text { como mecanismo social } \\
\text { de competição }\end{array}$ & \\
\hline $\begin{array}{l}\text { UA5 - Definição } \\
\text { meritocrática de aluno }\end{array}$ & \\
\hline $\begin{array}{l}\text { UA6 - Um sentido de } \\
\text { sucesso escolar } \\
\text { decorrente da } \\
\text { motivação e empenho } \\
\text { individual }\end{array}$ & \\
\hline $\begin{array}{l}\text { UA7 - A ideia do poder } \\
\text { do mérito atribuído ao } \\
\text { aluno }\end{array}$ & \\
\hline $\begin{array}{l}\text { UA8 - Avaliação } \\
\text { alinhada com a ideia } \\
\text { genérica de "mérito" } \\
\text { individual }\end{array}$ & \\
\hline $\begin{array}{l}\text { UA9 - Interseções } \\
\text { estabelecidas entre } \\
\text { avaliação, } \\
\text { objetivos/metas/compet } \\
\text { ências e mérito escolar }\end{array}$ & \\
\hline $\begin{array}{l}\text { UA10 - Enfoque nos } \\
\text { resultados individuais e } \\
\text { o direito de ser } \\
\text { reconhecido pelas } \\
\text { competências } \\
\text { adquiridas }\end{array}$ & \\
\hline $\begin{array}{l}\text { UA11 - O processo de } \\
\text { certificação como face } \\
\text { oficial de medição } \\
\text { (diferenciada) do mérito }\end{array}$ & $\begin{array}{l}\text { "b) Formar diplomados nas diferentes áreas de } \\
\text { conhecimento, aptos para a inserção em sectores } \\
\text { profissionais e para a participação no desenvolvimento da } \\
\text { sociedade, e colaborar na sua formação contínua;" }\end{array}$ \\
\hline $\begin{array}{l}\text { UA12 - "Terapias" } \\
\text { (pedagógicas) } \\
\text { alternativas para a } \\
\text { universalização } \\
\text { hierarquizada do mérito }\end{array}$ & \\
\hline $\begin{array}{l}\text { UA13 - A normalização } \\
\text { dos prémios de } \\
\text { mérito/excelência e a } \\
\text { ideia de recompensa }\end{array}$ & \\
\hline
\end{tabular}


Tabela 4 Referencial de codificação e categorização dos dados documentais relativo ao documento 3

\begin{tabular}{|c|c|c|}
\hline Categorias temáticas & Unidades de análise & Unidades de contexto \\
\hline \multirow{8}{*}{$\begin{array}{l}\text { CT1 - Disposições gerais } \\
\text { relativas à meritocracia } \\
\text { escolar (alunos) }\end{array}$} & $\begin{array}{l}\text { UA1 - O mérito como } \\
\text { ethos cultural do } \\
\text { sistema educativo }\end{array}$ & \\
\hline & $\begin{array}{l}\text { UA2 - Alusões do } \\
\text { sistema educativoà } \\
\text { justiça escolar e social }\end{array}$ & \\
\hline & \multirow{5}{*}{$\begin{array}{l}\text { UA3 - Uma arquitetura } \\
\text { burocrática do sistema } \\
\text { educativo baseada em } \\
\text { aprendizagens } \\
\text { diferenciadas e na } \\
\text { distribuição } \\
\text { diferenciada do saber } \\
\text { escolar }\end{array}$} & $\begin{array}{l}\text { "1 - É criado, na dependência direta do Ministro da } \\
\text { Educação e Ciência, um grupo de trabalho de reformulação } \\
\text { das Metas Curriculares, o qual tem por missão identificar o } \\
\text { conjunto de conhecimentos e capacidades essenciais que o } \\
\text { aluno tem de adquirir e desenvolver, por ano de } \\
\text { escolaridade ou ciclo, nas diferentes disciplinas dos } \\
\text { ensinos básico e secundário." }\end{array}$ \\
\hline & & $\begin{array}{l}\text { "i) Os conteúdos fundamentais que devem ser ensinados } \\
\text { aos alunos; }\end{array}$ \\
\hline & & $\begin{array}{l}\text { ii) A ordenação sequencial ou hierárquica dos conteúdos ao } \\
\text { longo das várias etapas de escolaridade; }\end{array}$ \\
\hline & & $\begin{array}{l}\text { iii) Os conhecimentos e capacidades a adquirir e a } \\
\text { desenvolver pelos alunos; }\end{array}$ \\
\hline & & $\begin{array}{l}\text { iv) Os padrões/níveis esperados do desempenho dos } \\
\text { alunos que permitam avaliar o cumprimento dos objetivos;" }\end{array}$ \\
\hline & $\begin{array}{l}\text { UA4 - Alusão ao mérito } \\
\text { como mecanismo } \\
\text { social de competição }\end{array}$ & \\
\hline \multirow{4}{*}{$\begin{array}{l}\text { CT2 - Relação da } \\
\text { condição de aluno com a } \\
\text { ideia de mérito }\end{array}$} & $\begin{array}{l}\text { UA5 - Definição } \\
\text { meritocrática de aluno }\end{array}$ & $\begin{array}{l}\text { "Tendo em atenção as prioridades estabelecidas pelo } \\
\text { Ministério da Educação e Ciência para o ensino com vista a } \\
\text { elevar os padrões de desempenho dos alunos é decisivo } \\
\text { que o desenvolvimento do novo Currículo Nacional: } \\
\text { (...) } \\
\text { Permita que todos os alunos tenham oportunidade de } \\
\text { adquirir um conjunto de conhecimentos e de desenvolver } \\
\text { capacidades fundamentais nas disciplinas essenciais;" }\end{array}$ \\
\hline & \multirow{2}{*}{$\begin{array}{l}\text { UA6 - Um sentido de } \\
\text { sucesso escolar } \\
\text { decorrente da } \\
\text { motivação e empenho } \\
\text { individual }\end{array}$} & $\begin{array}{l}\text { "Os padrões que se estabelecem devem ser traçados tendo } \\
\text { em conta a formação integral dos estudantes e a relevância } \\
\text { do ensino para o mundo real, refletindo o conhecimento e } \\
\text { as capacidades que os nossos jovens necessitam de } \\
\text { adquirir e desenvolver para o seu sucesso no futuro." }\end{array}$ \\
\hline & & $\begin{array}{l}\text { "Desta forma, o desenvolvimento do ensino será orientado } \\
\text { por Metas Curriculares nas quais são definidos, de forma } \\
\text { consistente, os conhecimentos e as capacidades } \\
\text { essenciais que os alunos devem adquirir, nos diferentes } \\
\text { anos de escolaridade ou ciclos e nos conteúdos dos } \\
\text { respectivos programas curriculares." }\end{array}$ \\
\hline & $\begin{array}{l}\text { UA7 - A ideia do poder } \\
\text { do mérito atribuído ao } \\
\text { aluno }\end{array}$ & \\
\hline
\end{tabular}




\begin{tabular}{|c|c|c|}
\hline \multirow{8}{*}{ CT3 - Avaliação e mérito } & $\begin{array}{l}\text { UA8 - Avaliação } \\
\text { alinhada com a ideia } \\
\text { genérica de "mérito" } \\
\text { individual }\end{array}$ & \\
\hline & \multirow{6}{*}{$\begin{array}{l}\text { UA9 - Interseções } \\
\text { estabelecidas entre } \\
\text { avaliação, } \\
\text { objetivos/metas/compet } \\
\text { ências e mérito escolar }\end{array}$} & $\begin{array}{l}\text { "Para cada disciplina e para cada etapa, devem } \\
\text { identificar-se, de forma clara: }\end{array}$ \\
\hline & & $\begin{array}{l}\text { Os conteúdos fundamentais que devem ser ensinados aos } \\
\text { alunos; }\end{array}$ \\
\hline & & $\begin{array}{l}\text { A ordenação sequencial ou hierárquica dos conteúdos ao } \\
\text { longo das várias etapas de escolaridade; }\end{array}$ \\
\hline & & $\begin{array}{l}\text { Os conhecimentos e capacidades a adquirir e a } \\
\text { desenvolver pelos alunos; }\end{array}$ \\
\hline & & $\begin{array}{l}\text { Os padrões/níveis esperados de desempenho dos alunos } \\
\text { que permitam avaliar o cumprimento dos objetivos. }\end{array}$ \\
\hline & & $\begin{array}{l}\text { Deste modo, revela-se crucial a reformulação das Metas } \\
\text { Curriculares para as diferentes disciplinas do ensino Básico } \\
\text { e Secundário, passando estas a assumirem-se, por todos e } \\
\text { em cada disciplina, como uma referência fundamental no } \\
\text { ensino." }\end{array}$ \\
\hline & $\begin{array}{l}\text { UA10 - Enfoque nos } \\
\text { resultados individuais e } \\
\text { o direito de ser } \\
\text { reconhecido pelas } \\
\text { competências } \\
\text { adquiridas }\end{array}$ & \\
\hline \multirow{3}{*}{$\begin{array}{l}\text { CT4 - Gestão escolar e } \\
\text { mérito }\end{array}$} & $\begin{array}{l}\text { UA11 - O processo de } \\
\text { certificação como face } \\
\text { oficial de medição } \\
\text { (diferenciada) do } \\
\text { mérito }\end{array}$ & \\
\hline & $\begin{array}{l}\text { UA12 - "Terapias" } \\
\text { (pedagógicas) } \\
\text { alternativas para a } \\
\text { universalização } \\
\text { hierarquizada do } \\
\text { mérito }\end{array}$ & \\
\hline & $\begin{array}{l}\text { UA13 - A normalização } \\
\text { dos prémios de } \\
\text { mérito/excelência e a } \\
\text { ideia de recompensa }\end{array}$ & \\
\hline
\end{tabular}


Tabela 5 Referencial de codificação e categorização dos dados documentais relativo ao documento 4

\begin{tabular}{|c|c|c|}
\hline Categorias temáticas & Unidades de análise & Unidades de contexto \\
\hline \multirow{5}{*}{$\begin{array}{l}\text { CT1 - Disposições } \\
\text { gerais relativas à } \\
\text { meritocracia escolar } \\
\text { (alunos) }\end{array}$} & $\begin{array}{l}\text { UA1 - O mérito como ethos } \\
\text { cultural do sistema educativo }\end{array}$ & $\begin{array}{l}\text { "Nestes termos, tendo em vista melhorar a qualidade do } \\
\text { que se ensina e do que se aprende, o presente diploma } \\
\text { procede à introdução de um conjunto de alterações } \\
\text { destinadas a criar uma cultura de rigor e de excelência, } \\
\text { através da implementação de medidas no currículo dos } \\
\text { ensinos básico e secundário." }\end{array}$ \\
\hline & \multirow[t]{2}{*}{$\begin{array}{l}\text { UA2 - Alusões do sistema à } \\
\text { justiça escolar e social }\end{array}$} & $\begin{array}{l}\text { "O acompanhamento e a avaliação dos alunos são } \\
\text { fundamentais para o seu sucesso, sendo importante } \\
\text { implementar medidas que incrementem a igualdade de } \\
\text { oportunidades, nomeadamente a criação temporária de } \\
\text { grupos de homogeneidade relativa em disciplinas } \\
\text { estruturantes, no ensino básico, atendendo aos } \\
\text { recursos da escola e à pertinência das situações." }\end{array}$ \\
\hline & & $\begin{array}{l}\text { "a) Adotar medidas que favoreçam a igualdade de } \\
\text { oportunidades, criando temporariamente grupos de } \\
\text { homogeneidade relativa em disciplinas estruturantes, } \\
\text { ao longo de todo o ensino básico, atendendo aos } \\
\text { recursos da escola e às circunstâncias concretas;" }\end{array}$ \\
\hline & \begin{tabular}{|l|} 
UA3 - Uma arquitetura \\
burocrática do sistema \\
educativo baseada em \\
aprendizagens diferenciadas \\
e na distribuição diferenciada \\
do saber escolar
\end{tabular} & \\
\hline & $\begin{array}{l}\text { UA4 - Alusão ao mérito como } \\
\text { mecanismo social de } \\
\text { competição }\end{array}$ & \\
\hline \multirow{3}{*}{$\begin{array}{l}\text { CT2 - Relação da } \\
\text { condição de aluno com } \\
\text { a ideia de mérito }\end{array}$} & $\begin{array}{l}\text { UA5 - Definição meritocrática } \\
\text { de aluno }\end{array}$ & \\
\hline & $\begin{array}{l}\text { UA6 - Um sentido de sucesso } \\
\text { escolar decorrente da } \\
\text { motivação e empenho } \\
\text { individual }\end{array}$ & \\
\hline & $\begin{array}{l}\text { UA7 - A ideia do poder do } \\
\text { mérito atribuído ao aluno }\end{array}$ & \\
\hline \multirow[t]{3}{*}{$\begin{array}{l}\text { CT3 - Avaliação } \\
\text { e mérito }\end{array}$} & $\begin{array}{l}\text { UA8 - Avaliação alinhada } \\
\text { com a ideia genérica de } \\
\text { "mérito" individual }\end{array}$ & $\begin{array}{l}\text { "1 - A avaliação constitui um processo regulador do } \\
\text { ensino, orientador do percurso escolar e certificador } \\
\text { dos conhecimentos adquiridos e capacidades } \\
\text { desenvolvidas pelo aluno. } \\
2 \text { - A avaliação tem por objetivo a melhoria do ensino } \\
\text { através da verificação dos conhecimentos adquiridos e } \\
\text { das capacidades desenvolvidas nos alunos e da } \\
\text { aferição do grau de cumprimento das metas } \\
\text { curriculares globalmente fixadas para os níveis de } \\
\text { ensino básico e secundário." }\end{array}$ \\
\hline & $\begin{array}{l}\text { UA9 - Interseções } \\
\text { estabelecidas entre avaliação, } \\
\text { objetivos/metas/competências } \\
\text { e mérito escolar }\end{array}$ & $\begin{array}{l}\text { "I) Promoção do rigor da avaliação, valorizando os } \\
\text { resultados escolares e reforçando a avaliação sumativa } \\
\text { externa no ensino básico; " }\end{array}$ \\
\hline & $\begin{array}{l}\text { UA10 - Enfoque nos resultados } \\
\text { individuais e o direito de ser } \\
\text { reconhecido pelas } \\
\text { competências adquiridas }\end{array}$ & $\begin{array}{l}\text { "1 - A avaliação constitui um processo regulador do } \\
\text { ensino, orientador do percurso escolar e certificador } \\
\text { dos conhecimentos adquiridos e capacidades } \\
\text { desenvolvidas pelo aluno." }\end{array}$ \\
\hline
\end{tabular}




\begin{tabular}{|c|c|c|}
\hline \multirow{8}{*}{$\begin{array}{l}\text { CT4 - Gestão escolar } \\
\text { e mérito }\end{array}$} & $\begin{array}{l}\text { UA11 - O processo de } \\
\text { certificação como face oficial } \\
\text { de medição (diferenciada) do } \\
\text { mérito }\end{array}$ & $\begin{array}{l}\text { "c) Cursos de nível básico de dupla certificação, } \\
\text { designadamente os cursos de educação e de formação } \\
\text { (CEF), destinados preferencialmente a alunos em risco } \\
\text { de abandono escolar, permitindo um ensino profissional } \\
\text { inicial como via privilegiada de transição para a vida } \\
\text { ativa e simultaneamente a continuação de estudos; " } \\
\text { "f) Reorientar o percurso de alunos que revelem } \\
\text { insucesso escolar repetido ou problemas de integração } \\
\text { na comunidade educativa, após uma avaliação da } \\
\text { situação e posterior encaminhamento para um percurso } \\
\text { que lhe confira certificado de qualificação profissional." } \\
\text { "1 - A avaliação constitui um processo regulador do } \\
\text { ensino, orientador do percurso escolar e certificador } \\
\text { dos conhecimentos adquiridos e capacidades } \\
\text { desenvolvidas pelo aluno." }\end{array}$ \\
\hline & \multirow{7}{*}{$\begin{array}{l}\text { UA12 - "Terapias" } \\
\text { (pedagógicas) alternativas } \\
\text { para a universalização } \\
\text { hierarquizada do mérito }\end{array}$} & $\begin{array}{l}\text { "a) Conceber, propor e gerir medidas específicas de } \\
\text { diversificação da oferta curricular; }\end{array}$ \\
\hline & & $\begin{array}{l}\text { b) Promover, através dos serviços de psicologia e } \\
\text { orientação, ações de orientação escolar e profissional e } \\
\text { de apoio ao desenvolvimento psicológico individual dos } \\
\text { alunos;" }\end{array}$ \\
\hline & & $\begin{array}{l}\text { "d) Implementar ações de acompanhamento e } \\
\text { complemento pedagógico, orientadas para a satisfação } \\
\text { de necessidades específicas; }\end{array}$ \\
\hline & & $\begin{array}{l}\text { e) Desenvolver ações de apoio ao crescimento e ao } \\
\text { desenvolvimento pessoal e social dos alunos, visando } \\
\text { igualmente a promoção da saúde e a prevenção de } \\
\text { comportamentos de risco; }\end{array}$ \\
\hline & & $\begin{array}{l}\text { f) Reorientar o percurso de alunos que revelem } \\
\text { insucesso escolar repetido ou problemas de integração } \\
\text { na comunidade educativa, após uma avaliação da } \\
\text { situação e posterior encaminhamento para um percurso } \\
\text { que lhe confira certificado de qualificação profissional." }\end{array}$ \\
\hline & & $\begin{array}{l}\text { "a) Adotar medidas que favoreçam a igualdade de } \\
\text { oportunidades, criando temporariamente grupos de } \\
\text { homogeneidade relativa em disciplinas estruturantes, } \\
\text { ao longo de todo o ensino básico, atendendo aos } \\
\text { recursos da escola e às circunstâncias concretas; c) } \\
\text { Promover, no } 1 .^{\circ} \text { ciclo, e através de apoios específicos, } \\
\text { um acompanhamento mais eficaz face ao desempenho } \\
\text { dos alunos, através de apoios específicos;" }\end{array}$ \\
\hline & & $\begin{array}{l}\text { "e) Prestar um maior acompanhamento aos alunos, } \\
\text { através de uma oferta de apoio ao estudo, no } 2 .^{\circ} \text { ciclo." }\end{array}$ \\
\hline & $\begin{array}{l}\text { UA13 - A normalização dos } \\
\text { prémios de mérito/excelência } \\
\text { e a ideia de recompensa }\end{array}$ & \\
\hline
\end{tabular}


Tabela 6 Referencial de codificação e categorização dos dados documentais relativo ao documento 5

\begin{tabular}{|c|c|c|}
\hline Categorias temáticas & Unidades de análise & Unidades de contexto \\
\hline \multirow{7}{*}{$\begin{array}{l}\text { CT1 - Disposições } \\
\text { gerais relativas à } \\
\text { meritocracia escolar } \\
\text { (alunos) }\end{array}$} & \multirow{4}{*}{$\begin{array}{l}\text { UA1 - O mérito como } \\
\text { ethos cultural do } \\
\text { sistema educativo }\end{array}$} & $\begin{array}{l}\text { "O Estatuto prossegue os princípios gerais e organizativos do } \\
\text { sistema educativo português, conforme se encontram estatuídos } \\
\text { nos artigos } 2 .^{\circ} \text { e } 3 .^{\circ} \text { da Lei de Bases do Sistema Educativo, } \\
\text { promovendo, em especial, o mérito, a assiduidade, a } \\
\text { responsabilidade, a disciplina, a integração dos alunos na } \\
\text { comunidade educativa e na escola, a sua formação cívica, o } \\
\text { cumprimento da escolaridade obrigatória, o sucesso escolar e } \\
\text { educativo e a efetiva aquisição de conhecimentos e capacidades." }\end{array}$ \\
\hline & & $\begin{array}{l}\text { "d) Ver reconhecidos e valorizados o mérito, a dedicação, a } \\
\text { assiduidade e o esforço no trabalho e no desempenho escolar } \\
\text { e ser estimulado nesse sentido;" }\end{array}$ \\
\hline & & $\begin{array}{l}\text { "h) Usufruir de prémios ou apoios e meios complementares } \\
\text { que reconheçam e distingam o mérito;" }\end{array}$ \\
\hline & & $\begin{array}{l}\text { "2 - São registadas no processo individual do aluno as } \\
\text { informações relevantes do seu percurso educativo, } \\
\text { designadamente as relativas a comportamentos meritórios e } \\
\text { medidas disciplinares aplicadas e seus efeitos." }\end{array}$ \\
\hline & $\begin{array}{l}\text { UA2 - Alusões do } \\
\text { sistema educativo à } \\
\text { justiça escolar e social }\end{array}$ & \\
\hline & \begin{tabular}{|l|} 
UA3 - Uma arquitetura \\
burocrática do sistema \\
educativo baseada em \\
aprendizagens \\
diferenciadas e na \\
distribuição diferenciada \\
do saber escolar
\end{tabular} & \\
\hline & $\begin{array}{l}\text { UA4 - Alusão ao mérito } \\
\text { como mecanismo social } \\
\text { de competição }\end{array}$ & $\begin{array}{l}\text { "2 - São registadas no processo individual do aluno as } \\
\text { informações relevantes do seu percurso educativo, } \\
\text { designadamente as relativas a comportamentos meritórios e } \\
\text { medidas disciplinares aplicadas e seus efeitos." }\end{array}$ \\
\hline \multirow{5}{*}{$\begin{array}{l}\text { CT2 - Relação da } \\
\text { condição de aluno } \\
\text { com a ideia de mérito }\end{array}$} & \multirow{3}{*}{$\begin{array}{l}\text { UA5 - Definição } \\
\text { meritocrática de aluno }\end{array}$} & $\begin{array}{l}\text { "O Estatuto prossegue os princípios gerais e organizativos do } \\
\text { sistema educativo português, conforme se encontram estatuídos } \\
\text { nos artigos } 2 .^{\circ} \text { e } 3 .^{\circ} \text { da Lei de Bases do Sistema Educativo, } \\
\text { promovendo, em especial, o mérito, a assiduidade, a } \\
\text { responsabilidade, a disciplina, a integração dos alunos na } \\
\text { comunidade educativa e na escola, a sua formação cívica, o } \\
\text { cumprimento da escolaridade obrigatória, o sucesso escolar e } \\
\text { educativo e a efetiva aquisição de conhecimentos e capacidades." }\end{array}$ \\
\hline & & $\begin{array}{l}\text { "d) Ver reconhecidos e valorizados o mérito, a dedicação, a } \\
\text { assiduidade e o esforço no trabalho e no desempenho escolar } \\
\text { e ser estimulado nesse sentido; }\end{array}$ \\
\hline & & $\begin{array}{l}\text { "e) Ver reconhecido o empenhamento em ações meritórias, } \\
\text { designadamente o voluntariado em favor da comunidade em } \\
\text { que está inserido ou da sociedade em geral, praticadas na } \\
\text { escola ou fora dela, e ser estimulado nesse sentido;" }\end{array}$ \\
\hline & \multirow[b]{2}{*}{$\begin{array}{l}\text { UA6 - Um sentido de } \\
\text { sucesso escolar } \\
\text { decorrente da motivação } \\
\text { e empenho individual }\end{array}$} & $\begin{array}{l}\text { "d) Ver reconhecidos e valorizados o mérito, a dedicação, a } \\
\text { assiduidade e o esforço no trabalho e no desempenho escolar } \\
\text { e ser estimulado nesse sentido;" }\end{array}$ \\
\hline & & $\begin{array}{l}\text { "3 - O dever de assiduidade e pontualidade implica para o } \\
\text { aluno a presença e a pontualidade na sala de aula e demais } \\
\text { locais onde se desenvolva o trabalho escolar munido do } \\
\text { material didático ou equipamento necessários, de acordo com } \\
\text { as orientações dos professores, bem como uma atitude de } \\
\text { empenho intelectual e comportamental adequada, em função } \\
\text { da sua idade, ao processo de ensino." }\end{array}$ \\
\hline
\end{tabular}




\begin{tabular}{|c|c|c|}
\hline & \multirow[b]{2}{*}{$\begin{array}{l}\text { UA7 - A ideia do poder } \\
\text { do mérito atribuído ao } \\
\text { aluno }\end{array}$} & \\
\hline & & \\
\hline \multirow{4}{*}{$\begin{array}{l}\text { CT3 - Avaliação e } \\
\text { mérito }\end{array}$} & $\begin{array}{l}\text { UA8 - Avaliação alinhada } \\
\text { com a ideia genérica de } \\
\text { "mérito" individual }\end{array}$ & \\
\hline & $\begin{array}{l}\text { UA9 - Interseções } \\
\text { estabelecidas entre } \\
\text { avaliação, objetivos/ } \\
\text { metas/competências e } \\
\text { mérito escolar }\end{array}$ & \\
\hline & $\begin{array}{l}\text { UA10 - Enfoque nos } \\
\text { resultados individuais e } \\
\text { o direito de ser } \\
\text { reconhecido pelas } \\
\text { competências } \\
\text { adquiridas }\end{array}$ & $\begin{array}{l}\text { "1 - Para efeitos do disposto na alínea h) do artigo } 7 .^{\circ}, \text { o } \\
\text { regulamento interno pode prever prémios de mérito destinados } \\
\text { a distinguir alunos que, em cada ciclo de escolaridade, } \\
\text { preencham um ou mais dos seguintes requisitos: } \\
\text { a) Revelem atitudes exemplares de superação das suas } \\
\text { dificuldades; } \\
\text { b) Alcancem excelentes resultados escolares; } \\
\text { c) Produzam trabalhos académicos de excelência ou realizem } \\
\text { atividades curriculares ou de complemento curricular de } \\
\text { relevância; } \\
\text { d) Desenvolvam iniciativas ou ações de reconhecida } \\
\text { relevância social. }\end{array}$ \\
\hline & & $\begin{array}{l}2 \text { - Os prémios de mérito devem ter natureza simbólica ou } \\
\text { material, podendo ter uma natureza financeira desde que, } \\
\text { comprovadamente, auxiliem a continuação do percurso } \\
\text { escolar do aluno." }\end{array}$ \\
\hline \multirow[b]{3}{*}{$\begin{array}{l}\text { CT4 - Gestão escolar } \\
\text { e mérito }\end{array}$} & $\begin{array}{l}\text { UA11 - O processo de } \\
\text { certificação como face } \\
\text { oficial de medição } \\
\text { (diferenciada) do mérito }\end{array}$ & \\
\hline & $\begin{array}{l}\text { UA12 - "Terapias" } \\
\text { (pedagógicas) } \\
\text { alternativas para a } \\
\text { universalização } \\
\text { hierarquizada do mérito }\end{array}$ & $\begin{array}{l}\text { "i) Beneficiar de outros apoios específicos, adequados às suas } \\
\text { necessidades escolares ou à sua aprendizagem, através dos } \\
\text { serviços de psicologia e orientação ou de outros serviços } \\
\text { especializados de apoio educativo; } \\
\text { t) Beneficiar de medidas, a definir pela escola, adequadas à } \\
\text { recuperação da aprendizagem nas situações de ausência } \\
\text { devidamente justificada às atividades escolares." }\end{array}$ \\
\hline & $\begin{array}{l}\text { UA13 - A normalização } \\
\text { dos prémios de } \\
\text { mérito/excelência e a } \\
\text { ideia de recompensa }\end{array}$ & $\begin{array}{l}\text { "1 - Para efeitos do disposto na alínea h) do artigo } 7 .^{\circ} \text {, o } \\
\text { regulamento interno pode prever prémios de mérito destinados a } \\
\text { distinguir alunos que, em cada ciclo de escolaridade, preencham } \\
\text { um ou mais dos seguintes requisitos: } \\
\text { a) Revelem atitudes exemplares de superação das suas } \\
\text { dificuldades; } \\
\text { b) Alcancem excelentes resultados escolares; } \\
\text { c) Produzam trabalhos académicos de excelência ou realizem } \\
\text { atividades curriculares ou de complemento curricular de } \\
\text { relevância; } \\
\text { d) Desenvolvam iniciativas ou ações de reconhecida relevância } \\
\text { social. } \\
2 \text { - Os prémios de mérito devem ter natureza simbólica ou } \\
\text { material, podendo ter uma natureza financeira desde que, } \\
\text { comprovadamente, auxiliem a continuação do percurso } \\
\text { escolar do aluno. } \\
3 \text { - Cada escola pode procurar estabelecer parcerias com } \\
\text { entidades ou organizações da comunidade educativa no } \\
\text { sentido de garantir os fundos necessários ao financiamento } \\
\text { dos prémios de mérito." }\end{array}$ \\
\hline
\end{tabular}


Tabela 7 Referencial de codificação e categorização dos dados documentais relativo ao documento 6

\begin{tabular}{|c|c|c|}
\hline Categorias temáticas & Unidades de análise & $\begin{array}{l}\text { Unidades de Foram retiradas as aspas, dado } \\
\text { não tratar-se de uma citação. contexto }\end{array}$ \\
\hline \multirow{4}{*}{$\begin{array}{l}\text { CT1 - Disposições gerais } \\
\text { relativas à meritocracia } \\
\text { escolar (alunos) }\end{array}$} & $\begin{array}{l}\text { UA1 - O mérito como ethos cultural } \\
\text { do sistema educativo }\end{array}$ & \\
\hline & $\begin{array}{l}\text { UA2 - Alusões do sistema educativo } \\
\text { à justiça escolar e social }\end{array}$ & \\
\hline & $\begin{array}{l}\text { UA3 - Uma arquitetura burocrática } \\
\text { do sistema educativo baseada em } \\
\text { aprendizagens diferenciadas e na } \\
\text { distribuição diferenciada do saber } \\
\text { escolar }\end{array}$ & $\begin{array}{l}\text { "3 - Os conhecimentos e capacidades a adquirir } \\
\text { e a desenvolver pelos alunos de cada nível e } \\
\text { de cada ciclo de ensino têm como referência os } \\
\text { programas das disciplinas, bem como as metas } \\
\text { curriculares a atingir por ano de escolaridade e } \\
\text { ciclo de ensino," }\end{array}$ \\
\hline & $\begin{array}{l}\text { UA4 - Alusão ao mérito como } \\
\text { mecanismo social de competição }\end{array}$ & \\
\hline \multirow{3}{*}{$\begin{array}{l}\text { CT2 - Relação da } \\
\text { condição de aluno com } \\
\text { a ideia de mérito }\end{array}$} & $\begin{array}{l}\text { UA5 - Definição meritocrática de } \\
\text { aluno }\end{array}$ & \\
\hline & $\begin{array}{l}\text { UA6 - Um sentido de sucesso } \\
\text { escolar decorrente da motivação e } \\
\text { empenho individual }\end{array}$ & \\
\hline & $\begin{array}{l}\text { UA7 - A ideia do poder do mérito } \\
\text { atribuído ao aluno }\end{array}$ & \\
\hline \multirow{3}{*}{ CT3 - Avaliação e mérito } & $\begin{array}{l}\text { UA8 - Avaliação alinhada com a } \\
\text { ideia genérica de "mérito" individual }\end{array}$ & \\
\hline & $\begin{array}{l}\text { UA9 - Interseções estabelecidas } \\
\text { entre avaliação, } \\
\text { objetivos/metas/competências e } \\
\text { mérito escolar }\end{array}$ & \\
\hline & $\begin{array}{l}\text { UA10 - Enfoque nos resultados } \\
\text { individuais e o direito de ser } \\
\text { reconhecido pelas competências } \\
\text { adquiridas }\end{array}$ & $\begin{array}{l}\text { "2 - No } 1 .^{\circ} \text { ciclo do ensino básico, a informação } \\
\text { resultante da avaliação sumativa interna } \\
\text { materializa-se de forma descritiva em todas as } \\
\text { disciplinas, com exceção de Português e de } \\
\text { Matemática no } 4 .^{\circ} \text { ano de escolaridade, a qual } \\
\text { se expressa numa escala de } 1 \text { a } 5 . "\end{array}$ \\
\hline \multirow{3}{*}{$\begin{array}{l}\text { CT4 - Gestão escolar } \\
\text { e mérito }\end{array}$} & $\begin{array}{l}\text { UA11 - O processo de certificação } \\
\text { como face oficial de medição } \\
\text { (diferenciada) do mérito }\end{array}$ & $\begin{array}{l}\text { "Nos cursos profissionais do ensino secundário é } \\
\text { alargada a carga horária da formação em contexto } \\
\text { de trabalho, com vista a desenvolver a } \\
\text { componente técnica da formação, permitindo aos } \\
\text { alunos uma aplicação dos conhecimentos } \\
\text { adquiridos e o desenvolvimento de novas aptidões } \\
\text { que facilitem quer a sua integração no mundo do } \\
\text { trabalho quer o prosseguimento de estudos." }\end{array}$ \\
\hline & $\begin{array}{l}\text { UA12 - "Terapias" (pedagógicas) } \\
\text { alternativas para a universalização } \\
\text { hierarquizada do mérito }\end{array}$ & $\begin{array}{l}\text { "... no } 1 .^{\circ} \text { ciclo, procede-se ao reforço curricular } \\
\text { de forma a permitir às escolas a tomada de } \\
\text { decisões relativamente à organização do Apoio } \\
\text { ao Estudo, da Oferta Complementar, assim como } \\
\text { à gestão dos tempos a lecionar em algumas } \\
\text { disciplinas. Promove-se, ainda, uma otimização } \\
\text { dos recursos no sentido de adequar as atividades } \\
\text { a desenvolver aos perfis dos docentes. A escola } \\
\text { assume um papel essencial na organização de } \\
\text { atividades de enriquecimento do currículo } \\
\text { fomentando uma gestão mais flexível e articulada } \\
\text { das diversas ofertas a promover." }\end{array}$ \\
\hline & $\begin{array}{l}\text { UA13 - A normalização dos prémios } \\
\text { de mérito/excelência e a ideia de } \\
\text { recompensa }\end{array}$ & \\
\hline
\end{tabular}


Tabela 8 Referencial de codificação e categorização dos dados documentais relativamente ao documento 7

CT1 - Disposições gerais relativas à meritocracia escolar (alunos)
CT2 - Relação da condição de aluno com a ideia de mérito

\begin{tabular}{l|l}
\hline Unidades de análise \\
\hline UA1 - O mérito como \\
ethos cultural do \\
sistema educativo
\end{tabular}

UA2 - Alusões do sistema educativo à justiça escolar e social

UA3 - Uma arquitetura
burocrática do sistema
educativo baseada em
aprendizagens
diferenciadas e na
distribuição
diferenciada do saber
escolar

Unidades de contexto

"Assim, o modelo integrado de avaliação externa das aprendizagens no ensino básico introduz as provas de aferição, a realizar em fases intermédias dos $1 .^{\circ}, 2 .^{\circ}$ e $3 .^{\circ}$ ciclos, mantendo as provas finais de ciclo, que visam avaliar o desempenho dos alunos, certificar a conclusão do $3 .^{\circ}$ ciclo do ensino básico e criar a possibilidade de prosseguimento de diferentes percursos escolares no ensino secundário. No essencial, as alterações introduzidas retomam a prática de aferição iniciada em 2000 , impondo-lhe a evolução que se exige, ao potenciar o trabalho junto de cada aluno e ao garantir a inclusão das áreas do currículo até aqui subvalorizadas em contexto de avaliação externa."

"No quadro deste processo, consolidou-se a evidência de que o modelo a adotar teria de ter subjacente um conjunto de pressupostos, nomeadamente que as dinâmicas de avaliação visam a melhoria das aprendizagens e o sucesso escolar dos alunos, que a avaliação contínua deve ser o instrumento por excelência da avaliação interna, devendo os instrumentos de avaliação externa atuar como recurso que potencie a avaliação interna realizada na escola, que a avaliação externa, centrada em apenas algumas disciplinas, conduz a um estreitamento curricular sentido pelos professores e pelas famílias, na medida em que não é produzida informação sobre outras áreas curriculares e, finalmente, que a aposta continuada na qualidade, pertinência e oportunidade da informação devolvida à escola, às famílias e aos outros agentes permitirá uma ação concertada e uma maior confiança no sistema."

\begin{tabular}{|c|c|c|}
\hline \multirow[t]{2}{*}{ 然 } & individual & \\
\hline & $\begin{array}{l}\text { UA7 - A ideia do poder } \\
\text { do mérito atribuído ao } \\
\text { aluno }\end{array}$ & \\
\hline \multirow[b]{2}{*}{ CT3 - Avaliação e mérito } & $\begin{array}{l}\text { UA8 - Avaliação } \\
\text { alinhada com a ideia } \\
\text { genérica de "mérito" } \\
\text { individual }\end{array}$ & \\
\hline & $\begin{array}{l}\text { UA9 - Interseções } \\
\text { estabelecidas entre } \\
\text { avaliação, objetivos/ } \\
\text { metas/competências e } \\
\text { mérito escolar }\end{array}$ & \\
\hline
\end{tabular}




\begin{tabular}{|c|c|c|}
\hline & \multirow[t]{2}{*}{$\begin{array}{l}\text { UA10 - Enfoque nos } \\
\text { resultados individuais e } \\
\text { o direito de ser } \\
\text { reconhecido pelas } \\
\text { competências } \\
\text { adquiridas }\end{array}$} & $\begin{array}{l}\text { "I) Promoção da capacidade reguladora dos instrumentos } \\
\text { de avaliação externa, através da sua utilização com } \\
\text { objetivos de aferição da forma como os alunos adquirem os } \\
\text { conhecimentos e desenvolvem as aprendizagens essenciais } \\
\text { nos diversos domínios curriculares;" }\end{array}$ \\
\hline & & $\begin{array}{l}\text { "3 - Os exames finais nacionais têm como objetivo avaliar o } \\
\text { desempenho dos alunos e certificar a conclusão do ensino } \\
\text { secundário nas ofertas formativas que prevejam avaliação } \\
\text { externa das aprendizagens, podendo ainda ser } \\
\text { considerados para efeitos de acesso ao ensino superior." }\end{array}$ \\
\hline \multirow[t]{5}{*}{$\begin{array}{l}\text { CT4 - Gestão escolar e } \\
\text { mérito }\end{array}$} & \multirow{2}{*}{$\begin{array}{l}\text { UA11 - O processo de } \\
\text { certificação como face } \\
\text { oficial de medição } \\
\text { (diferenciada) do mérito }\end{array}$} & $\begin{array}{l}\text { "o) Reconhecimento da importância da avaliação externa } \\
\text { para efeitos de certificação e prosseguimento de estudos no } \\
\text { final do } 3 .^{\circ} \text { ciclo do ensino básico e do ensino secundário }\end{array}$ \\
\hline & & $\begin{array}{l}\text { "1 - A avaliação constitui um processo regulador do ensino } \\
\text { e da aprendizagem, que orienta o percurso escolar dos } \\
\text { alunos e certifica as aprendizagens desenvolvidas." }\end{array}$ \\
\hline & \multirow{2}{*}{\begin{tabular}{|l|} 
UA12 - "Terapias" \\
(pedagógicas) \\
alternativas para a \\
universalização \\
hierarquizada do mérito
\end{tabular}} & $\begin{array}{l}\text { "c) Potenciar uma intervenção pedagógica atempada, } \\
\text { dirigida às dificuldades identificadas para cada aluno. }\end{array}$ \\
\hline & & $\begin{array}{l}\text { "1 - Em situações em que o aluno não desenvolva as } \\
\text { aprendizagens definidas para o ano de escolaridade que } \\
\text { frequenta, o professor titular de turma, no } 1 .^{\circ} \text { ciclo, ouvido o } \\
\text { conselho de docentes, ou o conselho de turma, nos } 2 .^{\circ} \text { e } 3 .^{\circ} \\
\text { ciclos, deve propor as medidas necessárias para superar as } \\
\text { dificuldades detetadas no percurso escolar do aluno." }\end{array}$ \\
\hline & $\begin{array}{l}\text { UA13 - A normalização } \\
\text { dos prémios de } \\
\text { mérito/excelência e a } \\
\text { ideia de recompensa }\end{array}$ & \\
\hline
\end{tabular}

No documento D1 a ideia de quadro de valor limita-se ao reconhecimento do mérito alcançado ao nível das capacidades ou atitudes exemplares na superação de dificuldades ou ao nível de iniciativas ou ações exemplares de benefício social ou comunitário, na escola ou fora dela. Algo suplantado pela ideia de excelência, esta focalizada no reconhecimento dos méritos dos alunos que revelem excelentes resultados académicos em termos curriculares (ordinária e/ou complementarmente).

Conforme é operado nas tabelas 2 a 8, o critério de análise que envolveu as respetivas categorias temáticas (Bardin, 1995) baseou-se numa classificação extraída do corpus documental de cada um dos documentos analisados, mediados, também, pelos referenciais teóricos que mobilizamos para o efeito. 


\section{Meritocracia escolar e sua(s) influência(s) na condição de jovem centralmente normalizada dos alunos: contributos para uma sociologia da educação e da juventude}

\section{Descrição dos dados}

Em termos relativos, a perceção que nos é dada pelas unidades semânticas inscritas nos domínios de indicadores relativos à análise da estrutura legal e normativa, que aqui convocamos em torno da discussão da tendência para a meritocratização da condição dos jovens que frequentam a escola pública portuguesa, percebe-se que tal efeito não se apresenta regular face ao conjunto dos diplomas legais que foram objeto de análise de conteúdo.

Congruentemente, tendo como referência a categoria temática das disposições gerais relativas à meritocracia escolar (alunos) (CT1), os diplomas legais que mais denunciam o interesse do legislador em prescrever a forma de olhar e conceber a juventude com o encargo de ser aluno, em linha com o argumento da meritocratização do sistema educativo são ilustrados pelos documentos D2 e D4, com especial incidência de unidades de contexto referentes às unidades de análise das alusões do sistema educativo à justiça e igualdade escolar e social (UA2). Relativamente às unidades semânticas relacionadas com a arquitetura burocrática do sistema educativo baseada em aprendizagens diferenciadas e na distribuição diferenciada do saber escolar(UA3), mantém-se presentes nos documentos D1, D3, D5, D6 e D7.

Quanto aos documentos D1, D3, D4 e D5 a análise efetuada permite que se observe, em linha com a categoria temática da relação da condição de aluno e o mérito, uma incidência semântica de conteúdo mais privilegiada pelo lado das unidades de análise da definição meritocrática de aluno (UA5).

Uma outra tendência que sobressai na nossa análise passa por se observar uma recorrente manifestação ao nível de unidades de contexto extraídas do conteúdo dos documentos D1, D5, D6 e D7, apresentando em comum unidades semânticas coincidentes com o enfoque nos resultados individuais e o direito de ser reconhecido pelas competências adquiridas (UA10). De forma similar, em sede dos diplomas legais coincidentes com a codificação D2, D4, D6 e D7, as unidades de contexto mais observadas coincidem com o processo de certificação como face oficial de mediação (diferenciada) do mérito (UA11). Apesar de se mostrar mais subtil, observa-se uma outra manifestação semântica no quadro da avaliação e o mérito (CT3), cujas unidades de contexto permitem analisar o conteúdo dos documentos D1, D3, D4 e D5 em linha com as interseções estabelecidas entre avaliação, objetivos/metas/competências e mérito escolar (UA9). 
A contrastar com aquelas regularidades semânticas e analíticas, fazem-se notar algumas ausências cuja manifestação, ainda que parcelar, intercalar e segmentada em função dos documentos em análise: a gestão e o mérito (CT4) mostra-se ausente do conteúdo dos documentos D1, D3 e D5, sem que sejam observadas unidades semânticas alusivas ao processo de certificação como face oficial de medição (diferenciada) do mérito (UA11); também a semântica das terapias (pedagógicas) alternativas para a universalização hierarquizada do mérito (UA12) mantém-se ausente no caso dos documentos D1, D2 e D3; quanto à normalização dos prémios de mérito/excelência e a ideia de recompensa (UA13) está ausente nos documentos D2, DD3, D4, D6 e D7; verifica-se a ausência de unidades semânticas alinhadas com a alusão ao mérito como mecanismo social de competição (UA4), nos documentos D1, D2, D3, D4, D6 e D7; faz-se notar, ainda, uma das principais ausências na semântica discursiva dos documentos D1, D3, D5 e D6, relativa às alusões do sistema educativo à justiça escolar e social (UA2).

\section{Discussão}

Com a pretensão de fazer notar os rumos formalmente instituídos da agenda meritocrática do sistema escolar português, privilegiamos a compreensão do modo como a estrutura legal e normativa mais coalizada com condição de aluno, tendo em conta a sua orientação para a educação de juventudes. Para tal, arrolamos as asserções suscitadas pelos domínios da prestação do serviço educativo, da organização e gestão escolar, da estrutura curricular e consequente oferta educativa/formativa, culminando na afirmação abundantemente focalizada nos resultados escolares dos alunos. Importa, ainda, que tais asserções sejam contextualizadas num alinhamento do ofício de aluno segundo as premissas paradigmáticas da escola a tempo inteiro (Despacho $\mathrm{n}^{\circ}$ 9265-B/2013), precisamente assente numa "planificação social" (Silva, 1976, pp. 160-162) especialmente conectada às agendas, privilegiadamente, laborais das famílias e da sociedade no seu todo.

Da nossa análise podem ser realçadas algumas tendências evolutivas do discurso legislativo no que concerne à maior ou menor propensão para a institucionalização de um efeito meritocrático do ofício de aluno. Assim, privilegiando as referências alusivas às evidências semânticas de presença forte ou explícita, diríamos que o argumento da meritocratização do sistema educativo e, consequentemente, da condição de aluno, em linha com a categoria de juventude que tal condição encerra, pode ser balizado por meio de três enfoques ou tendências, que a seguir exploraremos.

Referindo-nos à categoria temática das disposições gerais relativas à meritocracia escolar (alunos), aludimos, antes de tudo a uma interseção discursiva 
ocorrida entre o Decreto-Lei n. ${ }^{\circ}$ 139/2012 (estabelece os Princípios orientadores da organização e da gestão dos currículos dos ensinos básico e secundário, da avaliação dos conhecimentos a adquirir e das capacidades) e a Lei n. ${ }^{\circ}$ 51/2012 (aprova o Estatuto do Aluno e Ética Escolar). Dessa interseção, demos conta que ambos os diplomas legais permitem, de forma explícita, a associação a alusões ao sistema educativo e ao subsequente funcionamento da escola pública portuguesa das prerrogativas da justiça e igualdade escolar e social, ainda que acopladas a uma arquitetura burocrática do sistema educativo baseada em aprendizagens diferenciadas e na distribuição diferenciada do saber escolar. Neste enlace analítico e interpretativo, a agenda da meritocracia tem vindo a acomodar-se no sentido de confrontar e, até, seduzir as famílias e os jovens alunos da escola pública através da "cultura ansiosa do resultado" (Baudelot \& Establet 2009, p. 9). Caso será para dizer que se tem tornado relativamente fácil concordar com a semântica ideológica que resguarda a escola a tempo inteiro e o respetivo projeto de escolarização dos alunos e a consequente educação das juventudes, precisamente na lógica da hiperescolarização dos jovens, de que as famílias passam a ser cúmplices.

Daqui decorre o interesse em perpetuar a presença dos alunos na escola, dado que a reorganiza à sua feição ideológica e interesses produtivistas, com a aparência de uma escola mais aberta e mais disponível para atender às necessidades das famílias e dos alunos moldadas na forja ideológica do neoliberalismo mais radical, com um poderoso efeito de hiperescolarização dos alunos que, de outra forma, seriam um incómodo e entrave à atividade produtiva das famílias. Daqui, decorre a ideia de uma escola meritocrática que procura preparar os jovens para a atividade produtiva arquitetada mais a jusante, onde a racionalidade de fim de linha da dimensão meritocrática assume a configuração vocacionalista socioprofissional e produtivista (Pires, 2012). Algo que, tal como já antes observámos, que inscreve o ofício de aluno num mecanismo de alunização especialmente orientado para a sua preparação para desempenhar uma função confinada à lógica da divisão técnica do trabalho, no quadro de uma arquitetura social de elevada diferenciação hierárquica.

Neste caso, a prática da performatividade escolar em que os alunos se veem envolvidos tende a corresponder a uma evidente "radicalização do mandato neomeritocrático" (Afonso, 2013, p. 183), ainda que de forma subtil, aludindo a um falso efeito de universalização dos lugares de pódio da meritocracia escolar. Não obstante, face à pluralidade das bases socioculturais de partida dos alunos, a alusão aos valores da igualdade, justiça e universalidade do sistema educativo, tratando-se de prerrogativas originalmente antagónicas à ideologia da meritocracia, está dotada de uma subtileza excludente, recorrentemente, traduzida em terapias (pedagógicas) alternativas, ainda que tendam a resultar num efeito paradoxal de 
universalização hierarquizada do mérito escolar, onde não se evitam os "efeitos das desigualdades sociais sobre as desigualdades escolares" (Dubet, Duru-Bellat \& Vérétout, 2012, p. 31). Na verdade, as lógicas meritocráticas surgem, tendencialmente, envoltas num discurso oficial sedutor que tende a inserir os alunos numa dinâmica social e cultural que convoca as suas condições de jovens para o cumprimento de esquemas centralmente normalizados e definidos, em última instância como um conjunto de experiências de sucesso ou de fracasso escolar individuais, com repercussões ao nível das dinâmicas sociais em que os jovens são colocados mais a jusante, referindo-se ao "modo como tal condição é vivida a partir dos diversos recortes referidos às diferenças sociais - classe, gênero, etnia etc." (Dayrell, 2007, p. 1108).

Ou seja, associar as prerrogativas da justiça e da igualdade sociais às lógicas meritocráticas do sistema educativo é, no mínimo, hipocrisia discursiva, dada a sua tradução pelo argumento mais clarificado da violência simbólica (Bourdieu \& Passeron, 1982), sendo que o sistema educativo "fornece a aparência de legitimidade às desigualdades sociais, e sanciona a herança cultural e o dom social tratado como dom natural" (Bourdieu, 2007, p. 41).

A este conjunto de ideias poderá corresponder o triunfo obstinado do mérito composto por uma dupla face: o lado aparente da sua universalização e igualitarização, e o lado oposto da segregação, já que dizer que todos podem ser laureados pelo mérito constitui, per se, uma contradição insuperável, que se encobre a si própria. O mérito é um dote individual, desvinculando-se de quaisquer esquemas escolares, sociais e culturais holísticos, ainda que subversivamente convocados pela retórica das igualdades - leia-se, de oportunidades de sucesso - injustas, que, no fim resultarão naquilo a que François Dubet (2001, p. 5) designa por "desigualdades multiplicadas", correspondendo, neste caso, o mérito a uma espécie de "inflação escolar" (Giret, 2006, p. 1).

Depois, com a referência à categoria da relação da condição de aluno e o mérito, observa-se uma explícita definição meritocrática de aluno, estando a sua condição de jovem claramente alinhada com um sentido instituído de sucesso escolar acoplado à motivação e empenho individual.

Interpretativamente, aquele alinhamento, à luz de grande parte do discurso legislativo analisado, decorre, também, do enfoque nos resultados individuais que se espera que os alunos alcancem, de forma a legitimarem a sua ambição juvenil de verem concretizado o direito de ser reconhecidos pelas competências que o sistema educativo vai prescrevendo e exigindo que realizem (Despacho $n^{\circ}$ 5306/2012; Decreto-Lei $n^{\circ} 139$ /2012; Lei n ${ }^{\circ}$ 51/2012; Decreto-Lei n $\left.{ }^{\circ} 17 / 2016\right)$. Aliás, a essa prerrogativa de reconhecimento do mérito não parece ser alheio, por um lado, os 
diferentes processos de reconhecimento do valor, mérito e excelência académica dos (alguns) alunos (Despacho Normativo $\left.{ }^{\circ} 102 / 1990\right)$ e, por outro, o processo de certificação como face oficial de mediação (diferenciada) do mérito induzido pelo conteúdo do discurso legislativo em análise (Despacho Normativo $n^{\circ} 102 / 1990$; Lei $n^{\circ}$ 49/2005; Despacho $n^{\circ}$ 5306/2012; Lei no 51/2012). Algo que, de resto, coincide com "a consagração formal da premiação dos resultados académicos e dos comportamentos dos alunos" (Torres \& Quaresma, 2017, p. 578), recorrendo-se, por exemplo, aos "rendimentos materiais e simbólicos do diploma" (Miranda, 2017, p. 262), ainda que se admita que o diploma seja, apenas, parcialmente representativo do mérito alcançado pelos alunos (Tenret, 2011). A este propósito, ocorre dizer que é explicitada uma tendência para institucionalizar o valor da "performatividade e [das] distinções escolares no contexto da escola pública” (Torres \& Quaresma, 2017, p. 560).

Por último, e sem se mostrar absolutamente desconectado dos dois enfoques anteriores, na observação da relação estabelecida entre a avaliação e o mérito escolar, é evidente a intenção com que o legislador convoca as interseções estabelecidas entre avaliação, objetivos/metas/competências e mérito escolar dos alunos (Des-

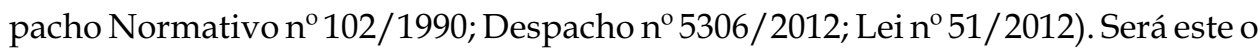
despontar daquilo que tem vindo a constituir a apologia crescente da excelência e performatividade académica dos alunos (Torres \& Palhares, 2016).

Uma outra tradução possível destes pressupostos alinha-se com a própria conceção política e ideológica do mérito, do valor e da excelência. Ou seja, tal conceção comporta, em si mesma, a legitimação do ato de avaliar e ponderar distintos valores de desempenhos escolares, pelo que o mérito encerra uma cultura do desempenho da política educacional inscrita no discurso oficial. Eis que, neste caso, no jogo escolar o mérito passa a ocupar o lugar de grande destaque, necessariamente, auxiliado pela avaliação, na sua dimensão mais desenvolvida da individual accountability, como artefacto simbólico que tem vindo a contribuir para um universo juvenil normalizado e institucionalizado no seio da escola pública francamente meritocratizada, mas que tende a transbordar para a estrutura social.

\section{Conclusão}

No que concerne, num primeiro momento de análise, à perspetivação das fronteiras filosófico-políticas e ideológicas que concorrem para uma crescente contextualização social dos papéis, dos saberes, dos processos de legitimação e institucionalização da condição de jovem no interior da escola pública, damos conta de uma meritocracia centralmente normalizada, com repercussões na sua integração social, tendencial e 
limitativamente a uma linha produtivista cultural e ideologicamente instituída. O mesmo discurso normalizador desenvolve uma retórica apologética da igualdade de acesso às oportunidades, anuindo, contudo, as desigualdades processuais, para muitos, originadas pelo estigma do self made man. Também aqui, encontramos uma apologia do mérito como o poder (meritum + cracia) com que cada aluno se mune ao longo do seu processo de escolarização, com francas probabilidades de se vir a reproduzir estruturalmente na arquitetura cultural e social em que se vai inserindo.

$\mathrm{Na}$ base daquele estigma está o Estatuto do Aluno e Ética Escolar (Lei n. ${ }^{\circ}$ 51/2012), que, ao apelar ao escrutínio dos resultados, subentende, na sua arqueologia jurídica, a materialização da ideologia dos resultados e do sucesso, rapidamente transformada na subsidiária ideologia do mérito e da excelência individuais dos alunos, num claro apelo à avaliação de talentos, habilidades e esforços individuais dos alunos. Ou seja, o jovem aluno é confrontado, a todo o tempo, com a ideia pragmática de ser avaliado quanto à sua capacidade para realizar resultados.

O fenómeno da escolarização dos jovens apresenta-se nas narrativas oficiais com recurso à enunciação de princípios meritocráticos explícitos, que exprimem expectativas produtivistas e performativas para todos os alunos. Neste caso, a noção de meritocracia normalizada encontra a sua principal base de legitimação na democracia dos méritos, na senda da qual a escola meritocrática proclama e reclama a sua função de instrumento de mobilidade social, ainda que balizada pelo efeito da normalização dos prémios de mérito/excelência e pela ideia de recompensa/penalização.

Para além da sua componente normativa, diríamos que as narrativas e racionalidades oficiais analisadas destilam um certo efeito sedutor nos alunos (e famílias), levando a que a agenda da meritocracia se tenha vindo a acomodar no sentido de confrontar e, até, fascinar os jovens alunos da escola pública através da cultura ansiosa do resultado centralmente prescrita, ainda que se dê o confronto fatal com um conjunto de experiências variáveis entre o sucesso e o fracasso escolar individuais.

Eis que desponta o triunfo obstinado do mérito composto por uma dupla face: o lado aparente da sua universalização e igualitarização, e o lado oposto da segregação, já que dizer que todos podem ser laureados pelo mérito constitui, per se, uma contradição insuperável do próprio sistema educativo, que o normaliza através das interseções estabelecidas entre avaliação, objetivos/metas/competências, performance e mérito escolar dos alunos. Também por isso nos permitimos fazer referência à narrativa do mérito escolar como uma apologia que encerra uma cultura do desempenho da política educacional inscrita no discurso oficial.

Assim, as nossas conclusões são aduzidas na base da hipótese da consolidação de um sistema educativo que se apresenta com uma forte tendência de meritocratização 
das juventudes que o frequentam, agilizando um exercício de epilogação da ocupação de aluno sincronizada com determinados modos de conhecimento escolar, com a conceção das relações entre o aluno/jovem e a sociedade e com um sistema de valores conforme e com as subjacentes conceções de educação como fator de produção e de aluno enquanto força produtiva da complexa agenda da sociedade neoliberal.

\section{Agradecimentos}

Este trabalho foi financiado pelo CI\&DETS - Centro de Estudos em Educação, Tecnologias e Saúde, do Instituto Politécnico de Viseu.

\section{Notas}

Por decisão pessoal, o autor do texto escreve segundo o novo acordo ortográfico.

\section{Referências}

Abramo, H. W. (2005). Condição juvenil no Brasil contemporâneo. In H. W. Abramo, \& P. P. M. Branco (Orgs.), Retratos da juventude brasileira: análises de uma pesquisa nacional (pp. 37-73). São Paulo: Instituto Cidadania e Fundação Perseu.

Adorno, T., \& Horkheimer, M. (1995). Dialética do esclarecimento. Rio de Janeiro: Zahar.

Afonso, A. J. (2012). Para uma concetualização alternativa de accountability em educação. Educação e Sociedade, 33(119), 471-484.

Afonso, A. J. (2013). Estratégias e percursos educacionais: das explicações às novas vantagens competitivas da classe média. In J. A. Costa, A. Neto-Mendes, \& A. Ventura (Orgs.), Xplika internacional: Panorâmica Sobre o Mercado das Explicações (pp. 167-188). Aveiro: Universidade de Aveiro.

Allen, A. (2011). Michael Young's The Rise of the Meritocracy: A Philosophical Critique. British Journal of Educational Studies. Pré-publicação online. Disponível em https://www.sheffield.ac.uk/polopoly_fs/1.155163!/file/philosophicalcritique.pdf

Almeida, J., \& Pinto, J. (1995). A Investigação em Ciências Sociais. Lisboa: Editorial Presença.

Aron, R. (1991). Estudos Sociológicos. Rio de Janeiro: Bertrand Brasil.

Ball, S. J. (2002). Reformar escolas, reformar professores e o terror da performatividade. Revista Portuguesa de Educação, 15(2), 3-23.

Barbosa, L. (2003). Igualdade e meritocracia: a ética do desempenho nas sociedades modernas. Rio de Janeiro: Fundação Getúlio Vargas Editora.

Bardin, L. (1995). Análise de conteúdo. Lisboa: Edições 70.

Bardin, L. (2011). Análise de conteúdo. São Paulo: Edições 70. 
Baudelot, C., \& Establet, R. (2009). L'élitisme républicain: l' école française à l'épreuve des comparaisons internationales. Paris: Éditions du Seuil.

Bertrand, Y., \& Valois, P. (1994). Paradigmas educacionais: escola e sociedades. Lisboa: Instituto Piaget.

Bogdan, R., \& Biklen, S. (1994). Investigação Qualitativa em Educação. Porto: Porto Editora.

Bonamigo, G. F. (2016). O problema do humano em Emmanuel Lévinas. O que nos faz pensar, 25(38), 139-159.

Bourdieu, P. (2007). A escola conservadora: as desigualdades frente à escola e à cultura. In M. A. Nogueira, \& A. M. Catani, Escritos de Educação (pp. 39-64). Petrópolis: Vozes.

Bourdieu, P., \& Passeron, J-C. (1982). A Reprodução: Elementos para uma teoria do sistema de ensino. Rio de Janeiro: Francisco Alves.

Contardo, Ó. (2008). Siútico. Arribismo, abajismo y vida social en Chile. Santiago: Editorial Vergara.

Dayrell, J. (2007). A escola "faz" as juventudes? Reflexões em torno da socialização juvenil. Educação \& Sociedade, 28(100), 1105-1128.

Decreto-Lei $n^{\circ}$ 139/2012, de 5 de julho. Princípios orientadores da organização e da gestão dos currículos e da avaliação dos conhecimentos dos ensinos básico e secundário. Diário da República, 1. ${ }^{a}$ série, 129, 3476-3491.

Decreto-Lei n. ${ }^{\circ}$ 91/2013, de 10 de julho. Procede à primeira alteração ao Decreto-Lei n. ${ }^{\circ} 139 / 2012$, de 5 de julho, que estabelece os princípios orientadores da organização e da gestão dos currículos dos ensinos básico e secundário, da avaliação dos conhecimentos a adquirir e das capacidades a desenvolver pelos alunos. Diário da República, 1. a série, 131, 4013-4015.

Decreto-Lei no 17/2016, de 4 de abril. Procede à terceira alteração ao Decreto-Lei n. ${ }^{\circ}$ 139/2012, de 5 de julho, que estabelece os princípios orientadores da organização e da gestão dos currículos e da avaliação das aprendizagens nos ensinos básico e secundário. Diário da República, 1. a série, 65, 1123-1127.

Despacho n ${ }^{\circ}$ 5306/2012, de 18 de abril. Padrões de desempenho dos alunos em Portugal. Diário da República, 2. ${ }^{\text {a }}$ série, 77, 13952-13953.

Despacho n ${ }^{\circ}$ 9265-B/2013, de 15 de julho. Define as normas a observar no período de funcionamento dos respetivos estabelecimentos, bem como na oferta das atividades de animação e de apoio à família (AAAF), da componente de apoio à família (CAF) e das atividades de enriquecimento curricular (AEC). Diário da República, 2. ${ }^{\text {a }}$ série, 134, 22210-(2) - 22210-(5).

Despacho Normativo $\mathrm{n}^{\circ}$ 102/1990, de 12 de setembro. Regulamenta os quadros de valor e de excelência. Diário da República, 1. a série, 211, 3729-3731.

Demazière, D., \& Dubar, C. (1997). Analyser les entretiens biographiques: L'exemple de récits d'insertion. Paris: Nathan.

Dubet, F. (2001). As Desigualdades Multiplicadas (M. C. D. Teixeira, Trad.). Revista Brasileira de Educação, (17), 5-19. (Obra original publicada em 2000). Disponível em https://www.scielo.br/pdf/rbedu/n17/n17a01.pdf 
Dubet, F., Duru-Bellat, M., \& Vérétout, A. (2012). As desigualdades escolares antes e depois da escola: organização escolar e influência dos diplomas. Sociologias, 14(29), 22-70. Disponível em http://www.scielo.br/pdf/soc/v14n29/a03v1429.pdf

Durkheim, É. (2008). A educação moral. Rio de Janeiro: Editora Vozes.

Duru-Bellat, M. (2010). L'école et les ambivalences du mérite. Revista Portuguesa de Pedagogia, (30 anos), 25-32.

Duru-Bellat, M., \& Tenret, É. (2012). Who's for Meritocracy? Individual and Contextual Variations in the Faith? Comparative Education Review, 5(2), 223-247.

Gallo, S. (2001). Filosofia, educação e cidadania. In A. J. Peixoto (Org.), Filosofia, Educação e Cidadania (pp. 133-153). Campinas: Alínea.

Gasparin, J. (2005). Uma Didática para a Pedagogia Histórico-Crítica. São Paulo: Autores Associados.

Giret, J.-F. (2006). [Duru-Bellat, M. L'inflation scolaire: les désillusions de la méritocratie]. Revue Française de Pédagogie, (155), 1-5. Disponível em https://journals.openedition.org/rfp/291

Goldthorpe, J., \& Jackson, M. (2008). Education-based meritocracy: The barriers to its realization. Stato e Mercato, (82), 31-60. Disponível em http://www.rivisteweb.it/doi/10.1425/26655

Lei $n^{\circ} 46 / 86$, de 14 de outubro. Lei de Bases do Sistema Educativo. Diário da República, $1 .^{\text {a }}$ série, $237,3067-3081$.

Lei $\mathrm{n}^{\circ} 31 / 2002$, de 20 de dezembro. Aprova o sistema de avaliação da educação e do ensino não superior. Diário da República, 1. ${ }^{a}$ série, 294, 7952-7954.

Lei $n^{\circ}$ 49/2005, de 30 de agosto. Segunda alteração à Lei de Bases do Sistema Educativo e primeira alteração à Lei de Bases do Financiamento do Ensino Superior. Diário da República, 1. ${ }^{a}$ série - A, 166, 5122-5138.

Lei $n^{\circ}$ 51/2012, de 5 de setembro. Estatuto do Aluno e Ética Escolar. Diário da República, 1. ${ }^{\text {a }}$ série, $172,5103-5119$.

McNamee, S. J., \& Miller, R. K., Jr. (2004). The Meritocracy Myth, 2(1). Disponível em http://www.ncsociology.org/sociationtoday/v21/merit.htm

Miletto, L. F. (2009). No mesmo barco, dando força, um ajuda o outro a não desistir Estratégias e trajetórias de permanência na educação de jovens e adultos. (Dissertação de Mestrado, Universidade Federal Fluminense, Niterói, Brasil). Disponível em http:/ / forumeja.org.br/sites/forumeja.org.br/files/ estrategias-e-trajetorias-depermanencia-na-eja-()-luis-fernando-mileto.pdf

Miranda, D. (2017). Rendimentos materiais e simbólicos do diploma de licenciatura em língua inglesa: estudo sobre egressos do curso de Letras da UFMG. In M. G. J. Setton, L. L. Torres, E. E. Gomes, T. Seabra, F. Jardim, B. Dionísio, \& M. C. Corrochano (Orgs.), Mérito, desigualdades e diferenças: cenários de (in)justiça escolar no Brasil e em Portugal (pp. 262-275). Alfenas: Universidade Federal de Alfenas. 
Moraes, R. (1999). Análise de Conteúdo. Revista Educação, 22(37), 1-13. Disponível em https://edisciplinas.usp.br/pluginfile.php/4125089/mod_resource/content/1/ Roque-Moraes_Analise\%20de\%20conteudo-1999.pdf

Nóvoa, A. (2009). Professores: imagens do futuro presente. Lisboa: Educa.

Palhares, J. (2014). Centralidades e periferias nos quotidianos escolares e não-escolares de jovens distinguidos na escola pública. Investigar em Educação, (1), 51-73.

Perrenoud, P. (1995). Ofício de aluno e sentido do trabalho escolar. Porto: Porto Editora.

Pires, C. A. (2012). A "escola a tempo inteiro" - operacionalização de uma política para o 1. ${ }^{\circ}$ ciclo. Uma abordagem pela "análise das políticas públicas" (Tese de Doutoramento, Universidade de Lisboa, Lisboa, Portugal).

Piza, S. L. T (1985). Empresa, Educação e Meritocracia: a propósito de Michael Young. Revista da Faculdade de Educação, 11(1/2), 211-222.

Poirier, J., Valladon, S., \& Raybant, P. (1983). Les récits de vie. Théorie et pratique. Paris: Presses Universitaires de France.

Quaresma, M. (2011). Democratização da Escola: perspectiva diacrônica sobre os mandatos escolares. In F. C. Lima, J. P. Sousa, \& M. J. Pires (Orgs.), Democratização e Educação Pública: Sendas e Veredas (pp. 190-216). São Luís: EDUFMA.

Ravitch, D. (2011). Vida e morte do grande sistema escolar americano: como os testes padronizados e o modelo de mercado ameaçam a educação. Porto Alegre: Sulina.

Rummert, S. M., \& Alves, N. (2010). Jovens e adultos trabalhadores pouco escolarizados no Brasil e em Portugal: Alvos da mesma lógica de conformidade. Revista Brasileira de Educação, 15(45), 511-528. Disponível em http://www.scielo.br/pdf/rbedu/v15n45/09.pdf

Silva, M. M. (1976). Os "discursos" de planificação social e os sistemas de exclusão que os demarcam. Análise Social, 12(45), 160-178. Disponível em http://analisesocial.ics.ul.pt/documentos/1223913546G1tNQ0xo3Zy70CG7.pdf

Tenret, É. (2011). L'École et la Méritocratie: représentations sociales et socialization scolaire. Paris: Presses Universitaires de France.

Torres, L. L. (2013). Rumo à excelência escolar: imposição política, opção organizacional ou efeito cultural? Educação: temas e problemas (12/13), 143-156.

Torres, L. L., \& Palhares, J. A. (2016). Escalando o pódio. A performatividade académica no ensino secundário. In M. G. Alves, L. L. Torres, B. Dionísio, \& P. Abrantes (Orgs.), A EDUCAÇÃO NA EUROPA DO SUL: Constrangimentos e Desafios em Tempos Incertos (615-640). Lisboa: FCSH, Universidade Nova de Lisboa.

Torres, L. L., \& Quaresma, M. L. (2017). The meritocratic ideal in education systems: the mechanisms of academic distinction in the international context. Education as Change, 21(1), 560-582. Disponível em https://repositorium.sdum.uminho.pt/bitstream/1822/47339/1/AS_224_art03.pdf

Valle, I. R., \& Ruschel, E. (2009). A meritocracia na política educacional brasileira (1930-2000). Revista Portuguesa de Educação, 22(1), 179-206.

Valle I. R. (2013). O lugar da educação (escolar) na sociologia de Pierre Bourdieu. Revista Diálogo Educacional, 13(38), 411-437. 
Young, M. (1961). The rise of the meritocracy, 1970-2033: An essay on education and equality. Middlesex: Penguin.

Data de submissão: 27/04/2020 | Data de aceitação: 03/11/2020 